\title{
PRETORIA STUDENT LAW REVIEW (2010) 4
}

\author{
Pretoria Tydskrif vir Regstudente \\ Kgatišobaka ya Baithuti ba Molao ya Pretoria
}

Editor in chief:
Ian Learmonth

\section{Editors:}

Ulrich Fobian

Jared Luke Schultz

Natasha Mandizha

Ashlin Perumal

Godwin Kakande

Assistant editors:

Khomotso Moshikaro

Justin Leach (March 2010 to May 2010)

Pretoria University Law Press PULP 


\title{
(2010) 4 Pretoria Student Law Review
}

\author{
Published by: \\ Pretoria University Law Press (PULP) \\ The Pretoria University Law Press (PULP) is a publisher, based in \\ Africa, launched and managed by the Centre for Human Rights and the \\ Faculty of Law, University of Pretoria, South Africa. PULP endeavours \\ to publish and make available innovative, high-quality scholarly texts \\ on law in Africa. PULP also publishes a series of collections of legal \\ documents related to public law in Africa, as well as text books from \\ African countries other than South Africa.
}

For more information on PULP, see www.pulp.up.ac.za

Printed and bound by:

BusinessPrint

Pretoria

\section{Cover design:}

Layout: Yolanda Booyzen, Centre for Human Rights

To submit articles, contact:

PULP

Faculty of Law

University of Pretoria

South Africa

0002

Tel: +2712420 4948

Fax: +27 123625125

pulp@up.ac.za

www.pulp.up.ac.za

ISSN: 1998-0280

(C) 2011 


\section{TABLE OF CONTENTS}

Editors' note

I. Learmonth

Why write?

K. Van Marle

Revisiting the bipolar distinction in the characterisation of armed conflicts

W. Ochieng

The material law protection of wild animals

JP. Liebenberg

Race and rac(ial)ism, the politics of peace and

friendship in a liberal constitution

J. Modiri

A call for a difference in treatment between child and adult offenders in the South African parole system: an international law perspective

I. Gueorguieva

Ambush Marketing: The Kulula.com perspective R. Kgobokoe

The great move towards openness in adoption N. Da Rocha

The state of temporary employment services in democratic South Africa

T. Nkabinde 


\section{EDITORS' NOTE}

After much ado the fourth edition of the little purple journal has arrived. Once again it includes articles which discuss varying areas of law, written by students from all levels of academia. As in each of the previous editions we are pleased to report that we received excellent articles from a number of first year undergraduate students and take particular delight in the publication of Joel Modiri's submission entitled Race and Racialism.

For the first time we have included an article from the opposite end of the spectrum, that being the work of a highly recognised legal academic writer, Professor Karin Van Marle, as a featured article. I would like to thank her for her submission and for the assistance she has provided to the editorial board.

The 2010 editorial board is also the first not to include any of the founding editors. Each year the journal which they started in 2007 has experienced growth in its circulation, as well an increase in the number and quality of the submissions received. I think it is appropriate to thank, Gus Waschefort, Johan Spies, Avani Singh and Jonathan Swanepoel for their role in establishing this journal. I further add that the PSLR editorial board eagerly carries on in their footsteps.

I would also like to thank my fellow editors for their assistance with the publication of this edition, in particular Jared Luke Schultz and Ulrich Fobian who arranged for the final compilation and publication of this edition. As well as Ashlin Perumal for the front cover.

Furthermore special thanks are due to Elzet Hurter, Professor Anton Kok, Lizette Besaans and the Heads Of Departments at the University of Pretoria Faculty of Law without whom administrative issues and the peer review process would not have been possible and, more importantly, this publication would never have succeeded in reaching print.

If interested in publishing your work with the PSLR please email the editorial board at pslr@up.ac.za; we are also available to answer any questions you may have from the same email address.

Ian Learmonth

Editor in chief 


\section{NOTE ON CONTRIBUTIONS}

We invite all students to submit material for the fourth edition of the Pretoria Student Law Review. We accept journal articles, case notes, commentary pieces, response articles or any other written material on legal topics. You may even consider converting your research memos or a dissertation chapter into an article.

Please visit our website at www.pslr.co.za for more information.

You may submit your contribution to pstr@up.ac.za.

Alternatively you may submit your contribution by hand at the office of the Dean of the Law Faculty:

Dean's Office

Faculty of Law

4th Floor

Law Building

Unversity of Pretoria

Pretoria

0002 



\section{WHY WRITE?}

by Karin van Marle*

\section{Introduction}

How to respond to the question why write? And the question, I hasten to add, why read? And maybe the most pertinent one, why think? For me these questions are members of the same family, and like most if not all families live together in precarious and sometimes troubling ways. Writing, without reading and thinking, could end up in one of those over-simplified presentations of family life, falsely portraying the home as a one-dimensional, unreflective, necessarily safe and uncritical entity. However, as a diligent student I will keep to my task at hand and attempt a contemplation of the first question.

Why write if by writing we mean something more than to text, to email, to Google, to facebook? Why write if by living in a globalised world it seems as if access to the universe and everything that it offers is merely a tap on a keyboard away? Why write if the ultimate aim of everything is one of functionality or economic gain?

John Caputo tells us that "we have it from Aristotle that life is hard. ${ }^{1}$ According to Max Weber we live in a 'disenchanted' world. ${ }^{2}$ For Giles Deleuze 'What we most lack is a belief in the world, we've quite lost the world, it's been taken from us. ${ }^{3}$ Friedrich Nietzsche lamented the shift from a world where the ideal played a central role in human reflection to a world where empirical observation occupies a central place. ${ }^{4}$ However, as Nietzsche aptly observed, the shift away from the ideal world resulted in the disappearance of both ideal and real. ${ }^{5}$ Marianne Constable, following Nietzsche, has noted a similar shift in US legal theory, how through the years legal theory left a belief and interest in the ideal of justice behind to be replaced by nothing. ${ }^{6}$ One reason to start and keep writing is to respond to and

* Karin van Marle, Department of Legal History, Comparative Law and Legal Philosophy.

$1 \mathrm{~J}$ Caputo Radical hermeneutics. Repetition, deconstruction and the hermeneutic project (1987) 1.

2 M Weber 'Science as a vocation' in H Gerth and CW Mills (eds) From Max Weber: Essays in sociology (1946) 155.

G Deleuze Negotiations (1995) 176.

F Nietzsche Twilight of the idols (1968).

Nietzsche (n 4 above) 40-41.

M Constable 'Genealogy and jurisprudence: Nietzsche, nihilism, and the social scientification of law' Law \& Social Inquiry 193 (1994) 551-590. 
engage with the hardness of life, the disenchantment of the world, the loss of the ideal of justice. By this I am not suggesting writing as a redemptive project, but rather as a way of underscoring the complexities raised by the various philosophical perspectives, or as Caputo states, 'restoring life to its original difficulty.'

Most of you will probably not find the above a convincing argument - why write if it might result in further complication rather than simplification, why highlight problems if you can't solve them? The reason for writing that most practising lawyers and probably law teachers will support and that might convince students about the importance of writing is that as future lawyers, future legal scholars, your survival and success will depend on writing and particularly good writing. The lucidity of the office memorandums, letters, heads of argument, contracts and many other legal documents that you will draft will be of the utmost importance. Success or failure might depend on the strength of your legal research and argument, often presented orally, but always accompanied by a written document. Writing and more pertinently good writing will be part of and affect your future life as a lawyer.

Of course there is more to writing than the construction of a good sentence, the enumeration of correct headings and the drafting of legal documents, although all of this is important. Not only life is 'hard', good writing is hard as well. A certain way of writing of course could contribute to the 'disenchantment' of and the 'lack of belief' in the world, and the loss of justice on the one hand, but another way of writing on the other hand could respond to it, could open a gap, leave a trace of re-imagining, re-enchantment. Anthony Kronman, in a reflection on what he calls 'living in the law' argues as follows about what makes a good lawyer:

To achieve competence in the practice of law one must, of course, master a considerable body of doctrine and be familiar with the distinctive forms of argument the law employs. The truly distinguished lawyer, however, the one who is recognised by his or her peers in the profession as an exemplary practitioner and whose work is marked by subtlety and imagination, possesses more than mere doctrinal knowledge and argumentative skill. What sets such a lawyer apart and makes him a model for the profession as a whole is not how much law he [or she] knows or how cleverly he [or she] speaks, but how wisely he [or she] makes the judgments that his [or her] professional task require. When one lawyers wishes to praise the work of another, the compliment he is most likely to pay him is to say that he is a person of sound judgment. Nothing counts more among practicing lawyers than this. ${ }^{8}$ $861-862$ 
Kronman raises the concern that 'beyond a certain point ... the rationalisation of the law is likely to turn us all, those who teach the law as well as those who make and practice it, into bureaucratic functionaries, characterless experts whose work requires knowledge, precision, and fairness, but never judgment ...'.9 The concern with judgement might be one aspect that could shape our writing in such a way that it amounts to lawyers and legal scholars re-imagining and re-enchanting the world, to be more than 'legal slot machines.'10 South-African poet and writer, Antje Krog, in her latest book, Begging to be black states that in order for her to understand something she has to write it, and 'while writing - writingly as it were - I find myself dissolving into, becoming towards what I am trying to understand.'11 Following Krog writing then could assist you in obtaining better understanding.

For law students this would mean that you should write over and above the writing that you are doing as part of your LLB curriculum office letters, heads of arguments, essays or a final year dissertation. Write for the PSLR; write for the student news paper; start your own news paper or journal; write stories, poems, and songs. Turn the question 'why write?' into an embrace, an imperative, as a way of living in the law, but also as an attempt in making sense of living in the world.

$9 \quad$ Kronman (n 7 above) 876.

10 See 'Round and round the bramble bush: From Legal Realism to Critical Legal Scholarship' Harvard Law Review (1982) 957 1669-1690.

11 Krog Begging to be black (2009) 92. 



\title{
REVISITING THE BIPOLAR DISTINCTION IN THE CHARACTERISATION OF ARMED CONFLICTS
}

\author{
by W Ochieng*
}

\section{Introduction}

Since the Geneva Conventions, the architecture of International Humanitarian Law (IHL) has been founded upon a distinction between international armed conflict and non-international armed conflict. Today, this claim stands to be revisited since international and noninternational armed conflicts are no longer strict organising frameworks for the categorisation of rules of armed conflicts. This is seen in that over fifty years ago, when the four Geneva Conventions were negotiated, the principles of sovereignty and non-intervention were the cornerstones of international law and while their force today is still apparent, the interdependence of states, and global concerns such as terrorism and the commission of widespread human rights violations have eroded the traditional inviolability of borders. The dichotomy in humanitarian law is as implausible today as it is also fundamentally unworkable given the current conditions of conflicts.

This dualist conception is no longer adequate to deal with current features of armed conflict, which do not fit neatly into the two categories and frequently contain mixed elements which thus make the task of classification highly complex. The codification of customary rules of international humanitarian law has narrowed the grounds on which the distinctions are predicated. In addition, the two regimes apply simultaneously on multiple situations. Moreover, the question of contemporary armed conflicts raises serious doubts as to whether the traditional understanding of international law still suffices to explain the complexities of modern day armed conflicts.

This essay seeks to offer a different perspective on armed conflicts by suggesting a systematic rethinking of the categorisation of conflict. It argues that some of the dilemmas of contemporary conflicts may be attenuated by a new conceptualisation of this bipolar distinction namely a need for a unitary conception of armed conflict.

* Walter Khobe Ochieng, LLB Candidate, Moi University Kenya. 


\section{The dualist conception of the law of armed conflict.}

IHL is largely codified in treaties, in particular the four 1949 Geneva Conventions $^{1}$ (the Conventions) and the two 1977 additional protocols (the Protocols). ${ }^{2}$ These instruments apply only to armed conflicts. The Conventions and Protocols establish a strict distinction between international and non-international armed conflicts, with the latter being governed by less detailed and less protective rules.

In the normal course of events, the term 'international armed conflict' refers to a conflict between two or more states. ${ }^{3}$ Common Article 2 of the Geneva Conventions of 1949 gives an insight into the definition of an international armed conflict by stating that the Conventions should apply:

To all cases of declared war or of any other armed conflict which may arise between two or more of the High Contracting Parties, even if the state of war is not recognised by one of them and to 'all cases of partial or total occupation', even if such occupation does not meet armed resistance.

In contrast, a non-international armed conflict is a confrontation between the existing governmental authority and groups of persons subordinate to this authority. This is carried out by force of arms within national territory and it reaches the magnitude of an armed riot or a civil war. ${ }^{4}$ Common Article 3 of the Geneva Conventions ${ }^{5}$ and

Convention [No I] for the Amelioration of the Condition of the Wounded and Sick in Armed forces in the Field, 12 August 1949, 75 UNTS 31-83; Convention [No II] for the Amelioration of the Condition of the Wounded, Sick and Shipwrecked members of Armed Forces at Sea, 12 August 1949, 75 UNTS 85-133; Convention [No III] relative to the Treatment of Prisoners of War, 12 August 1949, 75 UNTS 135-285 and Convention [No IV] relative to the protection of Civilian persons in Time of War, 12 August 1949, 75 UNTS 287-417.

2 Protocol [No I] Additional to the Geneva Conventions of 12 august 1949 relating to the protection of Victims of International Armed Conflicts, 8 June 1977, 1125 UNTS 3-434; Additional Protocol [No II] to the Geneva Conventions of 12 August 1949 , and relating to the protection of Victims of Non-international Armed Conflicts, 8 June 1977, 1125 UNTS 609-699.

3 Art 1 para 4 Additional Protocol (AP) I, however, provides that the term includes: '... armed conflicts in which peoples fight against colonial domination and alien occupation and against racist regimes in the exercise of their right to selfdetermination, as enshrined in the Charter of the United Nations and the Declaration on Principles of International Law concerning Friendly Relations and

4 Co-operation among states in accordance with the Charter of the United Nations.' In a non-international armed conflict each party shall be bound to apply, as a minimum, the fundamental humanitarian provisions of international law embodied in the four 1949 Geneva Conventions (Common Art 3), the 1954 Cultural Property Convention (art 19) and the 1977 Additional Protocol II.

5 Contains a series of rudimentary provisions dealing with minimum rights and duties, such as the requirements that those hors de combat be treated humanely and that the wounded and sick be collected and cared for, and the prohibition against murder, torture, hostage taking, humiliating and degrading treatment, and the passing of sentences and carrying out executions without a fair trial. 
AP II which is far more detailed, ${ }^{6}$ are the two instruments which expressly apply to non-international armed conflicts.

In two respects, AP II does not go as far as Common Article 3. First, whereas article 3 applies to any 'armed conflict not of an international character occurring in the territory of one of the High Contracting parties', AP II applies only to armed conflicts taking place in the territory of a high contracting party between its armed forces and dissident armed forces or other organised armed groups which, under responsible command, exercise such control over a part of the High Contracting party's territory as to enable them to carry out sustained and concerted military operations and to implement the Protocol. $^{7}$

In addition, article I(2) provides that: 'This Protocol shall not apply to situations of internal disturbances and tensions, such as riots, isolated and sporadic acts of violence and other acts of a similar nature, as not being armed conflicts.' AP II will, it seems, be applicable between the government of a state and a rebel movement, in contrast, article 3 is broad enough to cover a conflict between different rebel movements competing for power within a state where the government is not involved as such or has ceased to exist.

Although internal conflicts are, in principle, subject to a different and more limited legal regime than that which applies to an international armed conflict, it is possible that some or all of the law of international armed conflicts may become applicable in a conflict which was originally classified as internal. This is achievable through Common Article 3 which encourages parties to an internal conflict to conclude special agreements to bring other provisions of the Geneva Conventions into force between them. In addition, foreign intervention may have the effect of giving an internal conflict an international character, at least in some of its aspects. Thus, the Commission of Experts established by the United Nations Security Council to investigate allegations of war crimes in the conflicts in the former Yugoslavia stated in its report to the UN Secretary General that, although the classification of the various conflicts was a difficult matter:

The Commission is of the opinion ... that the character and complexity of the armed conflicts concerned, combined with the web of agreements on humanitarian issues the parties have concluded among themselves, justify an approach whereby it applies the law applicable in

6 D Forsythe 'Legal management of internal war: The 1977 protocol on noninternational armed conflicts' (1978) 72 American Journal of International Law 272.

7 Art I, para I AP II. 
international armed conflicts to the entirety of the armed conflicts in the territory of the former Yugoslavia. ${ }^{8}$

\section{The challenges posed by contemporary conflicts to international humanitarian law}

\subsection{The rise of non-international armed conflicts}

The post-World War II era has seen an increase in the frequency of non-international and internal armed conflicts. ${ }^{9}$ In addition to an increase in frequency, non-international armed conflicts also consume more lives, more resources and have been more protracted than contemporary international armed conflicts has been seen. ${ }^{10}$ Post-WWII era war casualties have also been more likely to be civilians rather than combatants.

Moreover, these non-international armed conflicts often failed to remain purely internal. Frequently, intervening factors, such as third state interference, would act to 'internationalise' the conflict, and turn an non-international armed conflict into what has been termed 'internationalised' armed conflict. ${ }^{11}$

\subsection{The emergence of a hybrid internationalised armed conflict}

Internationalised armed conflicts usually demonstrate characteristics of both internal and international armed conflicts, such as when two non-state groups fight one another within the boundaries of a single state, or where an insurgent group fights against its government, but one of the parties, usually the insurgent group, is equipped or otherwise assisted by a third state. ${ }^{12}$

Contemporary armed conflicts often pass through stages at which they are international and stages at which they are non-international. This type of conflict raises special problems regarding the temporal scope of application in the Geneva Conventions. Thus the phenomenon of internationalised conflicts which embody both

Interim Report of the Commission of Experts established pursuant to Security Council Resolution 780 (1992), UN Doc. S/25274 (26 January 1993), para 45. However, the Report of the Secretary General pursuant to para 2 of the Security Council Resolution 808 (1993), UN Doc. S/25704 (3 May 1993), containing a draft statute for an International War Crimes Tribunal adopts a more cautious approach.

9 Gleditsch and others 'Armed conflict 1946 -2001: A new dataset' (2002) 39 Journal of Peace Research 615.

10 S Tharoor 'The future of civil conflict' (1999) 16 World Policy Journal 8-9.

11 RR Baxter 'The evolving laws of war' (1972) Military Law Review 5.

12 The military intervention by Rwanda and Uganda in the Democratic Republic of Congo is a good illustration of an internationalised conflict. 
international and internal elements presents a very real obstacle to the continuation of the dualistic regulation.

\subsection{The place of transnational terrorist groups in international humanitarian law}

Different legal regimes apply to transnational terrorist groups, given the reality of splitting up various facets of the conflict to be international armed conflict and others as non-international armed conflicts, which may not be entirely satisfactory. Some aspects of the terrorist and counter-terror operations are non-international armed conflicts but there are issues on which the law, as it stands, is not adequate.

When and where terrorism and counter-terrorism operations manifest themselves, in either form of armed conflict, international humanitarian law applies. However, it is not always easy to categorise outbreaks of violence as international or non-international armed conflict, or to identify the status of the actors involved. This is because such armed conflicts span the territories of several states even though the armed hostilities are not international. This can make it difficult to identify the relevant normative framework to regulate the conduct of affected parties. ${ }^{13}$

The norms prohibiting acts of terrorism in non-international armed conflict are identical to those applicable in international armed conflict. Article 3 Common to the four Geneva Conventions prohibits acts of terrorism. ${ }^{14}$ Protocol II reaffirms and develops these rules. ${ }^{15}$ But neither article 3 nor Protocol II has a provision similar to article 35 of Protocol I, which, for international armed conflict, codifies the long established principle that parties to an armed conflict are not free to choose the methods or means of combat of their liking and in particular that those weapons which cause superfluous injury or unnecessary suffering are outlawed.

However, the ICTY has concluded that the more egregious crimes committed in a non-international armed conflict are to be considered

13 RA Barnes 'Of vanishing points and paradoxes: Terrorism and international humanitarian law' (2005) International Conflict and Security Law 129-159.

14 The article without actually using the words 'terrorism' prohibits the following acts at any time and in any place: (a) violence to life and person, in particular murder of all kinds, mutilation, cruel treatment and torture; (b) taking of hostages and (c) outrages upon personal dignity, in particular humiliating and degrading treatment.

15 Under the heading 'Humane treatment' of those who do not, or no longer, take part in military operations, art 4, para 2(d) even condemns 'acts of terrorism' outright as contrary to the law. Moreover, Additional Protocol II also codifies standards for the conduct of military operations in internal conflicts. 
as international crimes. ${ }^{16}$ This means that acts of terrorism committed in a non-international armed conflict may indeed be equated with grave breaches, as defined by the 1949 Geneva Conventions.

As for customary international law, a recent comprehensive survey undertaken under the auspices of the International Committee of the Red Cross (ICRC) has uncovered a large body of customary rules, the majority of which are claimed to apply to both international and non-international armed conflicts. ${ }^{17}$ It is of note, however, that the study has neither clarified the distinction between international and non-international armed conflicts - in particular cases where a conflict with a non-state actor extends beyond the borders of one state - nor has it defined the lower threshold at which violence amounts to an armed conflict (for non-international armed conflicts).

The Conventions and Protocol I apply to international armed conflicts. Common Article 2 to the Conventions states that they 'shall apply to all cases of declared war or of any other armed conflict which may arise between two or more of the High Contracting Parties.'18 Since only states can be parties to the Conventions and transnational armed groups are not states then it can be posited that the Conventions do not apply to conflicts between states and non-state actors. As for customary international law, there is no indication that the concept of international armed conflict under customary international law is broader. ${ }^{19}$

Some activities of (and against) transnational armed groups are nevertheless covered by the law of international armed conflicts, including all hostilities directed against the armed forces or the territory of one state by forces representing another state or acting de facto under the direction or control of that other state. ${ }^{20} \mathrm{~A}$ transnational group may well be under the direction and control of a state. IHL of international armed conflict will then apply. Similarly, the law of international armed conflicts applies when a state is directing hostilities against a transnational-armed group on the territory of another state without the agreement of the latter.

Therefore international rules do apply in the trial of a person prosecuted for a crime committed in a non-international armed conflict. See Prosecutor $v$ Tadic, (Appeal Judgment) IT-94-1-A, ICTY, 15 July 1999.

17 JM Henckaerts \& LD Oswald-Beck (eds) Customary international humanitarian law (2005) 5.

18 Article 2 Common to the Conventions; and art 1(3) of Protocol I refers to this provision, but art 1(4) expands the field of application to national liberation

19 W Lietzau, 'Combating terrorism: Law enforcement or war?' in MN Schmitt \& GL Beruto, (eds) Terrorism and International Law, Challenges and Responses (2002) 80.

Tadic (n 16 above) para 116-144. 
Hostilities between one or several states, on the one side, and a transnational armed group, on the other, which do not qualify under the above-mentioned criteria as international armed conflicts may be non-international armed conflicts covered by article 3 Common to the four Conventions and by Protocol II. This presupposes, firstly, that the hostilities meet the minimum threshold for a non-international armed conflict and secondly, that every armed conflict not classified as international is perforce a non-international armed conflict, even if it is neither internal nor limited to the territory of one single state.

The question of the extraterritorial application of Common Article 3 , examined in light of the more general evolution in humanitarian law favours the convergence between the law of international armed conflict and the law of non-international armed conflict. A result of this convergence is that individuals involved in a non-international armed conflict can now benefit from many of the protections once available only in the context of inter-state conflicts. In any event, notwithstanding continuing controversy over its content, there seems to be consensus supporting the proposition that the law of noninternational armed conflict applies extraterritorially.

As noted above, demonstrating the applicability of humanitarian law outside of a state's territory is facilitated by the fact that the bulk of the law of armed conflict was designed to apply in an interstate context, assuming that states would be acting on each other's territory. That some of these rules are now deemed to apply even in an internal setting does not lessen the presumption that they will still apply extraterritorially, at least insofar as they consist of prohibitions and do not purport to impose obligations on third states. ${ }^{21}$

If a transnational armed group is a party to an armed conflict, it has to respect the whole of IHL of non-international armed conflict that has been drawing closer in recent years to the full IHL of international armed conflicts. IHL prohibits, in both international and non-international armed conflicts, any act which could be classified as terrorist ${ }^{22}$ in particular attacks against civilians, acts or threats of violence, whose primary purpose is to spread terror among the civilian population, ${ }^{23}$ and indiscriminate attacks. ${ }^{24}$

21 J Cerone 'Jurisdiction and power: The intersection of human rights law \& the law of non-international armed conflict in an extraterritorial context' (2007) 40 Israel Law Review 2.

22 HP Gasser 'Acts of terror, terrorism and international humanitarian law,' (2002) 847 International Review of the Red Cross 556 and Marco Sass'oli 'International humanitarian law and terrorism' in Wilkinson and Steward (eds) Contemporary research on Terrorism (1987) 470-472.

23 See art 51(2) of Protocol I, art 13(2) of Protocol II, and corresponding rule of customary IHL (see Rules 1 and 2 of the ICRC Study (n 17 above) para 3-11)

24 See art 51(4) and (5) of Protocol I, for international armed conflicts and Rules 1114 of the ICRC Study (n 17 above) para 37-50, for all armed conflicts. 
To sum up, it can safely be said that the prohibition of recourse to terrorist acts is as firmly anchored in the law applicable in noninternational armed conflict as it is in rules governing international armed conflict. It is arguable that IHL, as it stands, was developed at another time and is not adequate for the new challenges raised by the contemporary kind of conflict with transnational groups. The law should therefore be adapted to new realities. There is a need to strengthen the mechanisms of implementation geared towards armed groups and this could be done without distinction between the characterisations of armed conflict.

\subsection{New methods of enforcement of the Geneva Conventions}

The Geneva Conventions also introduced universal jurisdiction for 'grave breaches' of the Conventions. Grave breaches are those violations of the Geneva Conventions that are considered especially egregious and are considered to be of such 'gravity and magnitude that they warrant their universal prosecution and repression.'25 'Grave breaches' are crimes committed against those persons and objects designated by the Conventions as specially protected. ${ }^{26}$ Such offences are perceived as attacks on international order.

The principle of universal jurisdiction allows any state to bring to trial a person or persons accused of committing certain crimes against international law, regardless of the location of commission of the crime against international law, or the nationality of the victim or perpetrator. By implementing a system of universal jurisdiction, the hope is that such crimes are punished. ${ }^{27}$

\subsection{Non-traditional tactics in international hostilities}

Finally, contemporary conflicts often involve the use of nontraditional war tactics that may require a reassessment of characterisation. Contemporary armed conflicts are being fought in multiple ways, not only by conventional armed forces but also by tactics typically not associated with armed conflicts including: intelligence and law enforcement action, economic and financial

Attorney General of Israel v Eichmann 196136 ILR 18, 50 (District Court of Jerusalem); affirmed in Attorney General of Israel v Eichmann 196236 ILR 2777, 282-83 (Supreme Court of Israel).

26 These include persons hors de combat, the wounded, sick or shipwrecked, prisoners of war and civilians subject to the territorial control of the detaining power or under the belligerent occupation of an occupying power. Objects protected under the Conventions include medical transports and medical units, non-defended localities and demilitarised zones and objects of cultural, historical or spiritual importance.

27 O Swaak-Goldman 'Recent developments in international criminal law: Trying to stay afloat between scylla and charybdis' (2005) 54 International Comparative Law Quarterly 697. 
sanctions, and special operations that may continue long after the conclusion of any significant troop engagement. ${ }^{28}$ In view of these emerging tactics, the difficulty emerges where answering whether internationalisation of an armed conflict accrues to a foreign state aiding in such supportive roles but not engaging in conventional warfare.

\subsection{Developments in treaty law}

A move towards extending treaties on international humanitarian law to cover internal as well as international conflicts has become apparent in recent years. The Amended Protocol II of 1996 to the UN Weapons Convention applies to non-international armed conflicts, ${ }^{29}$ as does the 1997 Ottawa Convention on the prohibition of AntiPersonnel Mines. ${ }^{30}$ Additionally, the ambit of the 1999 Second Hague Protocol for the Protection of Cultural Property in the Event of Armed Conflict encompasses non-international armed conflicts. ${ }^{31}$

The broad acceptance of these Conventions indicates that at the very least, the use of poison, poisoned weapons or asphyxiating gases should be criminalised in all armed conflicts. Recent developments such as the Blinding Laser Weapons Protocol ${ }^{32}$ and Amended Protocol II to the Certain Conventional Weapons Convention ${ }^{33}$ contains prohibitions and restrictions on the use of mines and other devices, and applies to non-international armed conflict as well as international armed conflict. ${ }^{34}$ These Conventions take into account new developments in international law thus the same philosophy should be extended to international humanitarian law.

Indeed, the convergence of the law of armed conflict is demonstrated by the continued inclusion in $\mathrm{IHL}$ treaties of the Martens Clause. All four of the 1949 Conventions, ${ }^{35}$ as well as both the

The temporal scope of application of international humanitarian law in contemporary conflicts' (2003) International Humanitarian Law Research Initiative 9.

29 Art 1(2) Amended Protocol II of 1996

30 the unconditional language of article 1'. See A Roberts \& $R$ Guelff Documents on the laws of war (2000) 646.

31 Art 22 Second Hague Protocol of 1999.

32 Protocol IV on Blinding Laser Weapons of 1995

33 Convention on Prohibition or Restrictions on the Use of Certain Conventional Weapons Which May be Deemed to be Excessively Injurious or to Have Indiscriminate Effects, 1342 UNTS 137.

34 Amended Protocol on Prohibitions or Restrictions on the Use of Mines, 35 ILM 1206.

35 GC I, art 63, para 4; GC II, art 62, para 4; GC III, art 142, para 4; and GC IV, art 158 , para 4. 
Protocols, ${ }^{36}$ included the Martens Clause $^{37}$ in their final adopted drafts, again restating the importance of the place of the principles of humanity, the dictates of public conscience, and the laws and customs of nations, in determining permissible conduct in all armed conflicts.

\subsection{Codification of customary international humanitarian law}

Since the Conventions apply as treaties in almost any international armed conflict, the question of whether their provisions have achieved the status of customary international law is significant in two aspects. Firstly, in that the decision of the International Court of Justice in Nicaragua $v$ USA ${ }^{38}$ shows that an international tribunal may sometimes be able to apply the provisions of customary international law even though it lacks the competence to apply the provisions of a multilateral treaty. Secondly, in dualist states ${ }^{39}$ treaties do not form part of national legislation and cannot be applied by national courts, whereas national courts can and do apply rules of customary international law. ${ }^{40}$ It seems likely that most of the provisions of the Conventions, if not all, would now be regarded as declaratory of customary international law. ${ }^{41}$

Most of the rules of customary IHL, particularly the parts stemming from the Conventions and Protocol II, apply evenly to all types of conflicts. ${ }^{42}$ Though there are few treaties that address noninternational conflict, ${ }^{43}$ the ICRC has determined that there are 133 rules of customary IHL that govern both international and noninternational conflict in an identical fashion; another nine that govern international conflict and that 'arguably' also govern noninternational conflict; and four rules which are similar, but not identical, in governing the two types of conflict. ${ }^{44}$ Only twelve of the 161 rules promulgated by the ICRC apply exclusively to international conflict. ${ }^{45}$

Art 1(2) of Protocol I and in the Preamble to Protocol II. The Martens Clause is also included in paragraph 5 of the preamble of the Conventional Weapons Convention.

37 In 1899, Fyodor Martens laid down the following principle for cases not covered by humanitarian law: '... Civilians and combatants remain under the protection and authority of the principles of international law derived from established custom, from the principles of humanity and from the dictates of public conscience.'

38 ICJ (1986) Reports 14.

39 Noticeably many commonwealth countries as well as Israel.

40 T Meron Human rights and humanitarian norms as customary international law (1989) 3-78.

41 As above.

42 ICRC Study (n 17 above).

43 As above.

44 n 17 above, 198-212.

45 That leaves three rules which are only applicable in non-international conflict. 
Although the Additional Protocols of 1977 have not yet achieved the near-universal acceptance achieved by the 1949 Geneva Conventions, many provisions of AP I are declaratory of customary international law thus applicable in all armed conflicts. ${ }^{46}$ Even those provisions of AP I, which have not yet achieved the status of rules of customary international law, have influenced public opinion and the perceptions of states as to what is permissible in conflict.

There is an undoubted move towards extending the provisions of law applicable in international armed conflicts to internal conflicts. The Tadic Interlocutory Appeal Decision has been instrumental in this regard. ${ }^{47}$ This decision confirmed the customary law status of common article $3,{ }^{48}$ the 'Core of Additional Protocol II of 1977' and article 19 of the Hague Convention for the Protection of Cultural Property in the Event of Armed conflict of $1954 .{ }^{49}$ Furthermore, the Tribunal asserted that customary rules governing internal conflicts included the protection of civilians from hostilities, in particular from indiscriminate attacks, protection of civilian objects, in particular cultural property, protection of all those who do not (or no longer) take active part in hostilities, as well as prohibition of means of warfare proscribed in international armed conflicts and ban of certain methods of conducting hostilities. ${ }^{50}$ As regards customary humanitarian law, the pronouncements of the ICTY are highly authoritative and progressive.

Aside from the progressive advancement of customary law there are further endeavours which symbolise the growing demand for a more unitary system of law such as the 'Declaration of Turku' which seeks to establish a minimum set of humanitarian standards which would apply in all armed conflicts. ${ }^{51}$ Furthermore, the 1999 Secretary General's Bulletin on Observance by United Nations (UN) Forces of International Humanitarian Law obliges all UN forces involved in peacekeeping or enforcement missions to respect fundamental norms of humanitarian law regardless of the characterisation of the conflict. $^{52}$

D Fleck (ed) The Handbook of Humanitarian law in Armed conflicts (1995) 497 As above, 96-127.

The customary law status of common article 3 was pronounced previously by the International Court of Justice, Case Concerning Military and Paramilitary Activities In and Against Nicaragua (Merits), Nicaragua $v$ United States (n 38 above) para 218.

Tadic (n 16 above) para 98.

As above, para 127.

UN Sub-Commission on Prevention of Discrimination and Protection of Minorities Minimum Humanitarian Standards 51st Session UN Doc. E/CN 4/1995/116 (1995). See also the Seoul Resolution on the Relevance of International Humanitarian Law in Today's Armed Conflicts Res/Seoul 42/SP/1 (2003).

Secretary General's Bulletin on Observance by UN Forces of International Humanitarian Law UN Doc ST/SGB/999/13 (1999). 


\section{Conclusion}

The effect of a rapidly globalising world has confirmed that a state's interests are hardly confined within its territories and thus countries are more prone to be affected by the goings on in the territories of its neighbours. This has led to the emergence of a pattern whereby internal conflicts often grow to international ones, and international conflicts spill over into internal ones.

Whilst there has been progress in ensuring that the rules of international humanitarian law applicable are no longer a 'skeleton compared with those which apply to international conflicts, ' 53 there still remains a difference in the law applicable in the two situations nevertheless. The Tadic Interlocutory Appeal Decision summarised this, emphasising the limitations in the extension of the law governing international armed conflicts to internal conflicts. ${ }^{54}$ The Appeal Chamber stated that:

only a number of rules and principles governing international armed conflicts have gradually been extended to apply to internal conflicts', and that 'this extension has not taken place in the form of a full and mechanical transplant of those rules to internal conflicts; rather, the general essence of those rules, and not the detailed regulation they may contain, has become applicable to internal conflicts. ${ }^{55}$

Policies should be amended to encourage compliance with all rules of international humanitarian law in the conduct of any armed conflict, irrespective of whether that conflict is characterised as internal or international. Compliance with the full body of rules of international humanitarian law in non-international conflicts undoubtedly presents practical problems, but it serves not only humanitarian interests but also operational requirements. ${ }^{56}$

The law regulating both types of conflicts needs also to be characterised by the drafting of a single international instrument that would embrace the humanitarian notion that victims in all situations of armed conflict, irrespective of the nature of the latter, are subject to the same suffering and should be helped in the same way.

C Greenwood 'International humanitarian law and united nations military operations,' (1998) 1 YIHL 3-9 Tadic (n 16 above) para 126.

As above.

International Institute for Humanitarian Law, Declaration on the Rules of International Humanitarian Law Governing the Conduct of Hostilities in NonInternational Armed Conflicts, IRRC, Sep -Oct 1990, 404-8. 


\title{
THE MATERIAL LAW PROTECTION OF WILD ANIMALS
}

\author{
by JP Liebenberg*
}

\section{Introduction}

The aim of this article is to consider the protection of wild animals and other living natural resources in South Africa from a material law perspective. To ensure completeness both the procedural law and problems with enforcement will be briefly considered. Possible improvements and solutions to difficulties will also be submitted.

This article will focus mostly on the pre-1994 conservation ordinances ${ }^{1}$ which still apply in the nine new provinces. ${ }^{2}$ Wild animals are protected in these provincial laws on a species based approach where animals are listed in categories and each category is provided with a different degree of protection. ${ }^{3}$ These ordinances are the main source of law which deal with the conservation, protection and exploitation of wild animals, indigenous plants and freshwater fish in South Africa and is usually referred to as 'wildlife law.'4

\section{History, development and scope of conservation law}

The origins of conservation law can be traced back to the seventeenth century where, upon the arrival of colonial settlers in the Cape, five placaats were promulgated to protect gardens, lands and trees from destruction. ${ }^{5}$ After the creation of the Union of South Africa in 1910, nature conservation was left as a matter of provincial competence and their respective nature conservation departments. ${ }^{6}$ The current South African Constitution designates nature conservation to be a matter of concurrent competence of the national and provincial spheres of government. ${ }^{7}$

\footnotetext{
J Liebenberg, fourth year LLB student, University of Pretoria.

Ordinance 19 of 1974 of the Cape; Ordinance 8 of 1969 of the Free State; Ordinance 12 of 1983 of Transvaal; Ordinance 15 of 1974 of Natal and the previous homelands had their own conservation laws which still apply.

Glazewski Environmental Law in South Africa (2005) 365.

As above.

As above.

As above; Rabie \& Fuggle Environmental management (1992) 13.

Glazewski (n 3 above) 365.

As above.
} 
Historically, these ordinances have been focussed on the establishment of protected areas, the conservation of wild animals, indigenous plants and freshwater fish; which was also thought of as the full scope of nature conservation. ${ }^{8}$ More recently, this way of thought has been put aside to make way for a much broader definition which encompasses more than just conservation and includes management and income generation in order to conserve biodiversity and sustain life support systems and ecosystems of interdependent species. 9 The main focus has been on the idea to make conservation profitable, this is as result of the government's decreasing ability and willingness to subsidise the managing of protected areas. ${ }^{10}$

Societal pressure has also recently been increasing for the ethical treatment of animals, which raises a Constitutional question of the rights of animals, which is discussed below. ${ }^{11}$ Other aspects, like laws relating to hunting, ecotourism and recreation should also be included and seen in this context. ${ }^{12}$

After the adoption of the Interim and Final Constitution the four provinces became nine and incorporated the four homelands, which had their own individual laws relating to conservation. ${ }^{13}$

Nature conservation is now a matter of national as well as provincial concurrent competence, many of the previous nature conservation authorities are now also burdened with administering environmental management laws without having the capacity or the knowledge and expertise to do so. ${ }^{14}$ This added responsibility has led to a type of 'legal pluralism' that Du Plessis describes as 'legal chaos'. ${ }^{15}$ This confusion has been alleviated to some extent with the promulgation of the Environmental Conservation Extension Act 100 of 1996 and the Environmental Laws Rationalisation Act 51 of $1997 .{ }^{16}$

\section{International law}

\subsection{International wildlife agencies}

The main international and inter-governmental agencies dealing with international aspects of wildlife are the United Nations Environmental Program (UNEP) and the United Nations Commission on Sustainable

As above.

As above.

As above.

As discussed in part 4 of this paper.

Glazewski (n 3 above) 366.

As above.

As above.

As above; Du Plessis 'Integration of exiting environmental legislation in the Provinces' (1995) 2 South African Journal of Environmental Law and Policy 23.

16 Glazewski (n 3 above) 366. 
Development (CSD). ${ }^{17}$ They are responsible for the formulation of the Principles for Global Consensus on the Management, Conservation and Sustainable Development of all Types of Forests (UNCED Forest Principles) and Agenda 21. ${ }^{18}$ UNEP is responsible for the adoption of many of the wildlife conventions to which South Africa is a party. ${ }^{19}$

The World Conservation Union (WCU) is the most important international non-governmental organisation, which includes both governmental and non-governmental members, which has been playing a very important role in developing treaties to conserve natural resources and wildlife. ${ }^{20}$ For example, it played an important role in preparing the preliminary texts for a number of conventions which have been developed at later negotiations like the International Convention on Biodiversity. ${ }^{21}$ Other active NGO's in the field of nature conservation include Greenpeace, Friends of the Earth and the World Wildlife Fund (WWF). ${ }^{22}$

\subsection{International wildlife conventions}

Important wildlife conventions that South Africa has adopted include: the 1973 Convention on International Trade in Endangered Species of Wild Fauna and Flora (CITES); the Convention on the Conservation of Migratory Species of Wild Animals (the Bonn Convention or the CMS) and the Convention on Biological Diversity. ${ }^{23}$

\section{The Constitution and wildlife protection}

\subsection{Wildlife rights and the Bill of Rights}

South Africa has one of the most progressive and liberal Constitutions and Bill of Rights in the world, yet it does not go so far as to confer rights to animals. ${ }^{24}$ This was done despite animal rights groups campaigning vigorously for the inclusion of animal rights during the negotiation process of the South African Constitution. ${ }^{25}$ It is submitted that a reasonable compromise which would probably have satisfied animal rights groups would have been, instead of giving animals rights, giving people a duty to treat animals humanely. ${ }^{26}$ 
The focus on animal rights conforms to international trends as more attention is being paid to the topic of animal rights and the ethical treatment of animals. ${ }^{27}$

The proponents of animal rights argue that animals suffer if mistreated just like human beings and that rights should not be arbitrarily withheld from the one species and not the other. ${ }^{28}$ Although some of their arguments are valid and thought provoking, the ultimate aim of the animal rights movement is to eliminate human use and exploitation of animals. ${ }^{29}$ It is submitted that this is disproportionate and does not accord with the interests of society.

The ethical concerns about the humane treatment, prevention of cruelty and unnecessary killing of animals have been raised locally in South Africa along with the international community. ${ }^{30}$ This is evident from the promulgation of South African legislation like the Animals Protection Act 71 of 1962, the Performing Animals Act 24 of 1935 and the Societies for the Prevention of Cruelty to Animals Act 169 of 1993. ${ }^{31}$ These acts protect domestic animals mostly but do include wild animals in their ambit. 32

The argument to extend some rights to animals is a valid one and not completely unrealistic if one considers that slaves and women used to be thought of as having no rights. ${ }^{33}$ All of the above aside, it is probably not the right time in South Africa's political context to consider animal and wildlife rights, as inequalities on the human front are still to be dealt with properly. 34

\subsection{The Constitution and administration of nature conservation}

As indicated above, ${ }^{35}$ nature conservation has historically been under the complete control of the provinces independently. ${ }^{36}$ The Constitution has now changed that by stating: 'Nature conservation excluding national parks, national botanical gardens and marine resources' is a matter of concurrent national and provincial competence. ${ }^{37}$ The same is true for the 'environment' which is also

As above.

As above.

As above.

As above.

As above.

As above.

As above.

As above.

As discussed in part 1 of this paper.

Glazewski (n 3 above) 371.

Glazewski (n 3 above) 371; Constitution of the Republic of South Africa, 1996, Schedule 4. 
subject to concurrent competence of national and provincial control. 38

\section{Nature conservation laws in the former provinces and homelands}

\subsection{Introduction}

It is necessary to deal with the four nature conservation ordinances from the previous four provinces because they are still in place and still apply in some of the new nine provinces as they exist today. ${ }^{39}$ They are applied as follows:

- Nature and Environmental Conservation Ordinance (Cape); ${ }^{40}$ applies to the new provinces of Western Cape, Eastern Cape and Northern Cape and to some areas of the North West. ${ }^{41}$

- Nature Conservation Ordinance (Transvaal); 42 applies to Gauteng and the Northern Province. ${ }^{43}$ Mpumalanga province, which was part of the Transvaal, has adopted and passed new legislation and will be seen in paragraph 3.7.

- Nature Conservation Ordinance (Orange Free State); ${ }^{44}$ still applies in the Free State Province.

- Nature Conservation Ordinance (Natal); ${ }^{45}$ applied in KwaZulu-Natal but has been substantially supplemented by the KwaZulu-Natal Nature Conservation Management Act, ${ }^{46}$ which is elaborated in paragraph 4(7), as well as by the KwaZulu-Natal Nature Conservation Management Amendment Acts. ${ }^{47}$

\subsection{General approach in the Provincial ordinances}

\subsubsection{Introduction}

The general approach, which all four provinces have used, is to distinguish between conservation inside and outside reserves. ${ }^{48}$ Each

Glazewski (n 3 above) 371; Constitution of the Republic of South Africa, 1996 , Schedule 4.

Glazewski (n 3 above) 371.

Ordinance 19 of 1974.

Amended by the Western Cape Nature Conservation Laws Amendment Act 3 of 2000; Glazewski (n 3 above) 374.

Ordinance 2 of 1983.

The Cape Ordinance and former Bophuthatswana legislation also applies in the North West Province; Glazewski (n 3 above) 374.

Ordinance 8 of 1969.

Ordinance 15 of 1974

Act 9 of 1997.

Acts 5 of 1999 and 7 of 1999; Glazewski (n 3 above) 374.

Glazewski (n 3 above) 375. 
of the ordinances contains enabling provisions which allow the provincial authorities to establish provincial reserves. ${ }^{49}$ Outside reserves, the focus is more directed to the protection of an individual species of animal or plant, rather than the protection of entire ecosystems. ${ }^{50}$ The four ordinances do not mention threatened or endangered species specifically but rather refer to general categories like 'ordinary game', 'protected game' and 'specially protected game' and these then contain lists of specific species. ${ }^{51}$ The respective schedules of the old ordinances and the new provincial laws provide for the following categories:

- The Cape Ordinance ${ }^{52}$ lists the following categories: protected wild animals; endangered flora; protected flora; noxious aquatic growths. ${ }^{53}$

- The Orange Free State Ordinance ${ }^{54}$ lists the following six categories: protected game; ordinary game; specified wild animals; exotic animals; aquatic plants and protected plants. ${ }^{55}$ Also in a later schedule 'Hunting at night' is mentioned and lists the species to which the provisions apply. ${ }^{56}$

- The Transvaal Ordinance ${ }^{57}$ lists the following twelve categories: protected game(including a sub schedule on specially protected game); ordinary game; protected wild animals; wild animals to which s43 applies (this deals with the possession of certain listed wild animals); exotic animals; invertebrates; problem animals; trout waters; prohibited aquatic growths; protected plants and specially protected plants. ${ }^{58}$

- Mpumalanga Nature Conservation $\mathrm{Act}^{59}$ list the following fourteen categories in its schedules: specially protected game; protected game(this schedule includes amphibians, reptiles, mammals and birds); ordinary game; protected wild animals; wild animals to which the provisions of $\mathrm{s} 33$ do not apply (this section deals with possession); exotic animals to which s34 applies (this section deals with certain prohibitions); invertebrates; problem animals; fly fishing waters; prohibited aquatic growths; protected plants; specially protected plants; invader weeds and plants; unique communities. ${ }^{60}$ This Act repealed the KaNgwane Nature Conservation Act 3 of $1981 .^{61}$

As above.

As above.

As above.

Ordinance 19 of 1974.

Schedule 1 to 5; Glazewski (n 3 above) 375.

Ordinance 8 of 1969.

Schedule 1 to 6; Glazewski (n 3 above) 375.

Schedule 8; Glazewski (n 3 above) 375.

Ordinance 12 of 1983.

Schedules 2 to 12; Glazewski (n 3 above) 375.

Act 10 of 1998.

Schedules in Act 10 of 1998; Glazewski (n 3 above) 375.

Glazewski (n 3 above) 375. 
- The KwaZulu-Natal Conservation Amendment Act ${ }^{62}$ lists the following four categories to which different degrees of protection apply: ${ }^{63}$ specially protected indigenous animals; protected indigenous animals; specially protected indigenous plants and protected indigenous plants. 64

One can see a similarity in all these lists of the different protected categories, although they are not the same, the word 'game' is mentioned in all of them except for the Cape Ordinance, probably because hunting is not that predominant, at least in the Western Cape, although quite a big generator of income for the Eastern Cape. 65

\subsubsection{Summary}

The schedules above protect species in various different ways in the respective provinces; some have absolute protection; whilst others have permit requirements like bag limits, hunting seasons, prohibitions on certain hunting methods, etc. ${ }^{66}$ This system of provincial regulation holds many advantages because a certain species might be endangered in one province but not in others or, one species may be a problem in one province but not in others. ${ }^{67}$ It is therefore, easily adaptable to local ecological circumstances. ${ }^{68}$ One of the problems of this system is that it requires constant vigilance and maintenance by the entire community to make sure that it remains up to date and it also demands the monitoring of different species in the provinces and, thus requires a rather complicated administrative and technical infrastructure which is sometimes beyond the capabilities of the under-resourced provincial governments. ${ }^{69}$

\subsection{Administration of the conservation laws}

Many of the provinces have moved towards the trend of converting their respective nature conservation departments into statutory authorities in the form of Boards, following the lead of KwaZulu-Natal and their Nature Conservation Service (KZN NCS) which are, arguably, the leaders in nature conservation in South Africa. ${ }^{70}$ The national sphere has also done this with the South African National Parks (SANP, formerly the National Parks Board).

Act 5 of 1999.

Glazewski (n 3 above) 375.

Schedule 7; Glazewski (n 3 above) 375.

Glazewski (n 3 above) 376.

As above.

As above.

As above.

As above.

As above. 
The main issue with this is that the boards in the different provinces have very different types of jurisdictions. ${ }^{71}$ Some have placed only nature conservation, and not environmental management, as their sole competence, others are considering placing only protected areas under their jurisdiction and leaving general nature conservation outside reserves in the hands of the provincial authorities. ${ }^{72}$

\subsection{The conservation of wild animals}

Most of the Provincial Ordinances referred to above refer to both 'wild animals' and 'game.' The former, generally, is widely defined; the Cape Provincial Ordinance, for instance, defines wild animals as follows: 73

Any live vertebrate animals (including bird or reptile or the egg of such animal, bird or reptile but excluding any fish or any ostrich used for farming purposes and the egg thereof) belonging to a non-domestic species and includes any such animal which is kept or has been born in captivity.

None of the Provincial Ordinances refer to ownership of wild animals and it is, therefore, left to the common law. ${ }^{74}$ The South West African Ordinance, which still applies in Namibia, has a similar provision to the Game Theft Act with regard to ownership of wild animals. ${ }^{75}$

The various ordinances do provide for similar measures to control and regulate hunting of wild animals. ${ }^{76}$ The Cape Provincial Ordinance provides that 'endangered wild animals' may not be hunted at all at any time and in any circumstances. ${ }^{77}$ 'Protected wild animals' on the other hand may be hunted during certain times, namely hunting season, subject to permit requirements and conditions. ${ }^{78}$ Typical control measures implemented include the laying down of hunting seasons, bag limits, prohibitions on using certain types of hunting methods, ${ }^{79}$ the use of certain weapons ${ }^{80}$ and use of certain calibres of firearms in respect of certain species. ${ }^{81}$

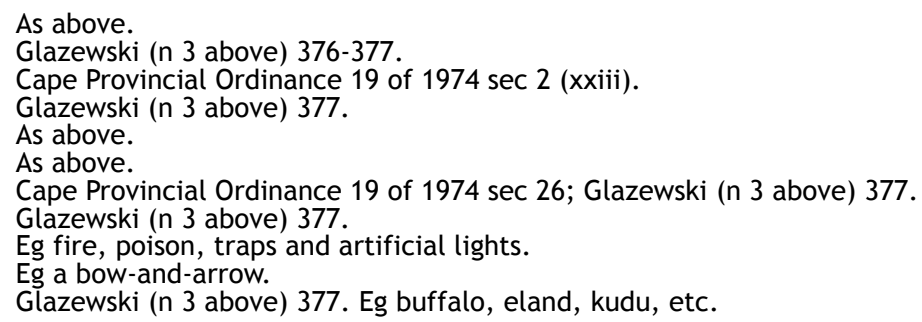




\section{The protection of wildlife in current Provincial legislation}

\subsection{Eastern Cape}

\subsubsection{The Nature Conservation Act ${ }^{82}$}

One has to consider the Ciskei Nature Conservation Act, ${ }^{83}$ hereafter referred to as 'the Act', when considering Eastern Cape legislation, as it still forms part of the legislation, in that part province that was part of the former self-governed state of Ciskei. ${ }^{84}$ Many of the provisions are similar to the Provincial Ordinances but are only written in plain and accessible English. ${ }^{85}$

The Act contains various chapters on the conservation and utilisation of wild animals, ${ }^{86}$ indigenous pants, ${ }^{87}$ nature reserves and water catchment areas, ${ }^{88}$ and fish. ${ }^{89}$ The Act also contains certain very innovative chapters which do not have counterparts in the provincial ordinance like chapters on hiking trial systems ${ }^{90}$ and sea, seashore and coastal conservation areas. ${ }^{91}$ The chapter on hiking systems includes a provision on hiking over private land. ${ }^{92}$ It is submitted that a provision like this could be a useful provision for the entire Southern South Africa.

The Act also contains a provision which resembles the 'limited development area' provision provided for in the Environmental Conservation Act, which has never been invoked, and the Transkei also has a similar Nature Conservation Act. ${ }^{93}$

\subsubsection{Legislative developments}

The Eastern Cape has instigated many public response and participation projects with the view to replace the Cape Ordinance ${ }^{94}$ and to establish its own nature conservation board. ${ }^{95} \mathrm{~A}$ draft paper,

Act 10 of 1987 (Ciskei).

Act15 (70) 25 September 1987.

Glazewski (n 3 above) 379.

As above.

Chapter 2 of the Act.

Chapter 3 of the Act.

Chapter 4 of the Act.

Chapter 7 of the Act.

Chapter 5 of the Act.

Chapter 6 of the Act.

See sec 38 of the Act.

Decree 9 (environmental conservation) Transkei in Special Gazette 70 (51) 24 July 1992.

94 Ordinance 19 of 1974

95 Glazewski (n 3 above) 380. 
the Draft Green Provincial Environmental Green Paper, ${ }^{96}$ has already been produced in order to meet this end. ${ }^{97} \mathrm{~A}$ departmental draft Nature Conservation Bill has also been produced. ${ }^{98}$ A Provincial Parks Board has also been established in terms of the Provincial Parks Board Act ${ }^{99}$ which has already been enacted. ${ }^{100}$ All of these steps will help to consolidate nature conservation laws which come from Transkei, Ciskei and the Cape Ordinance into a comprehensive Eastern Cape Nature Conservation Act. ${ }^{101}$

\subsection{Free State}

The Free State still operates under the Orange Free State Ordinance ${ }^{102}$ as discussed in paragraph 5.2.1 above. ${ }^{103} \mathrm{~A}$ Bill has however been published, namely the Free State Environmental Conservation Bill, which appears to be more focussed on environmental management than nature conservation. ${ }^{104}$ The Qwaqwa Nature Conservation $\mathrm{Act}^{105}$ is also still operative in the Free State Province. ${ }^{106}$

\subsection{Gauteng}

Gauteng Province still operates under the old Transvaal Nature Conservation Ordinance ${ }^{107}$ as discussed in paragraph 5.2.1 above. ${ }^{108}$ Like the other ordinances it includes chapters on the declaration of provincial nature reserves, ${ }^{109}$ wild animals, ${ }^{110}$ professional hunting, ${ }^{111}$ problem animals, ${ }^{112}$ fisheries, ${ }^{113}$ indigenous plants ${ }^{114}$ and endangered and rare species of fauna and flora. ${ }^{115}$ An interesting and unique chapter also provides for the trading and preservation of cave

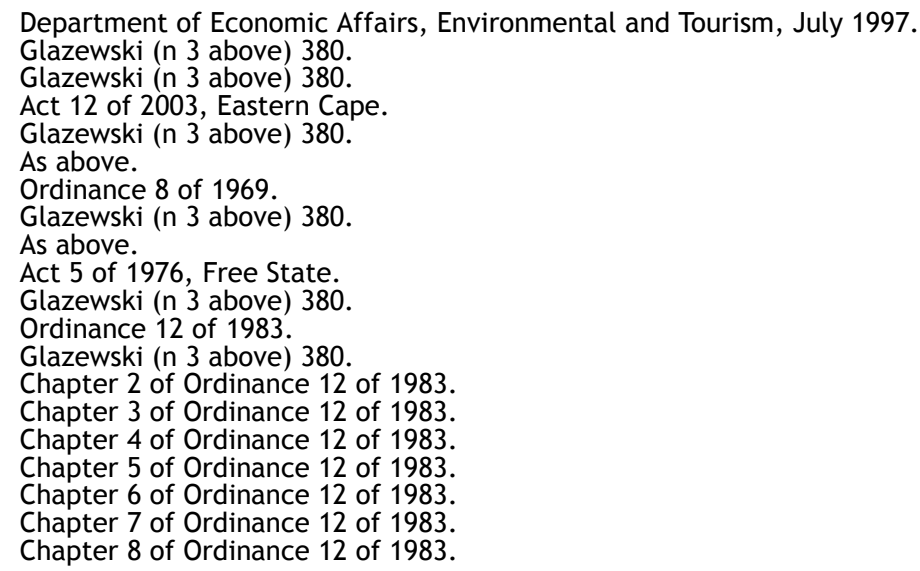


formations. ${ }^{116}$ Chapter 1 provides for the 'continued existence of the nature conservation advisory board. ${ }^{117}$

\subsection{KwaZulu-Natal}

KwaZulu-Natal Province has replaced its Nature Conservation Ordinance, ${ }^{118}$ as discussed in 5.2.1 above, with the KwaZulu-Natal Nature Conservation Management Act. ${ }^{119}$ This Act creates a new statutory body ${ }^{120}$ which replaces the former Natal Parks Board and incorporates the former KwaZulu Bureau of Natural Resources to form the KwaZulu-Natal Nature Conservation Service as well as the KwaZulu-Natal Nature Act. ${ }^{121}$ The Nature Conservation Ordinance, ${ }^{122}$ however, is still in place in conjunction with the other legislation. ${ }^{123}$

\subsection{Mpumalanga}

The Mpumalanga Province enacted the Eastern Transvaal Parks Board Act $^{124}$ after the creation of the nine new provinces but before the name changes. ${ }^{125}$ This Act established the Board and sets out its powers, functions and any other related matters. ${ }^{126}$ The title of the Act refers to the 'Parks Board' but in reality the Act applies to nature conservation in the entire province and not only in the protected areas. ${ }^{127}$ The Act states that the main object of the Board is: 'to provide effective conservation management of the natural resources of the Province, and to promote the sustainable utilisation thereof'. ${ }^{128}$ It can be seen from this that not only nature conservation but also environmental management in the entire province is the duty of this body. Included in its functions are things like "inventorying, assessing, and monitoring natural resources in the Province.'129 The Mpumalanga Nature Conservation Act ${ }^{130}$ was also passed in order to refine the old Transvaal Ordinance ${ }^{131}$ and is still in force. ${ }^{132}$ Other

116 Chapter 9 of Ordinance 12 of 1983.

117 Glazewski (n 3 above) 380.

118 Ordinance 15 of 1974

119 Act 9 of 1997, KwaZulu-Natal.

1205247 Provincial Gazette Extraordinary 18 December 1997; Glazewski (n 3 above) 380.

121 Act 29 of 1992, KwaZulu-Natal. Glazewski (n 3 above) 380.

122 Ordinance 15 of 1974.

123 Glazewski (n 3 above) 380.

124 Act 6 of 1995, Mpumalanga; N 41(89) Provincial Gazette Extraordinary 29 September 1995.

125 Glazewski (n 3 above) 380.

126 As above.

127 As above.

128 Sec 14; Glazewski (n 3 above) 381.

129 Sec 15(1)(a); Glazewski (n 3 above) 381

130 Act 10 of 1998, Mpumalanga.

13112 of 1983.

132 Glazewski (n 3 above) 381. 
Acts which are also still applicable in the province regarding nature conservation include the Bophuthatswana Nature Conservation Act, ${ }^{133}$ the Lebowa Nature Conservation Act $^{134}$ and the Kangwane Nature Conservation Act. ${ }^{135}$

\subsection{Northern Cape}

The Northern Cape Province is currently applying the Cape Nature and Environmental Conservation Ordinance. ${ }^{136}$ This is the most ill equipped province in the country concerning nature conservation as there is only one nature conservation officer for the entire province in the Department of Agriculture and Nature Conservation. ${ }^{137}$

\subsection{Limpopo}

The Limpopo Environmental Management Act $^{138}$ has recently been passed in the Limpopo Province. ${ }^{139}$ This piece of legislation has a heavy burden as it has to consolidate laws and institutions from four previous homelands which existed in its area, namely Lebowa, Venda, Gazankulu and KanGwane. ${ }^{140}$

\subsection{North West}

The North West Province has established a body corporate, the North West Parks and Tourism Board, ${ }^{141}$ in terms of the North West Parks and Tourism Board Act. The objects of the Board are not nature conservation in the broad sense but do include: ${ }^{142}$

the establishment, development, and efficient management of a network of formally protected areas in order to conserve indigenous biodiversity, representative samples of natural ecosystems and habitats of critically important or threatened species.

The board must, in addition to that, also facilitate and ensure development and promotion of tourism in the province. ${ }^{143}$ The North West Board is, therefore, only focussed on protected areas and not like some other provinces, ${ }^{144}$ where the boards are charged with

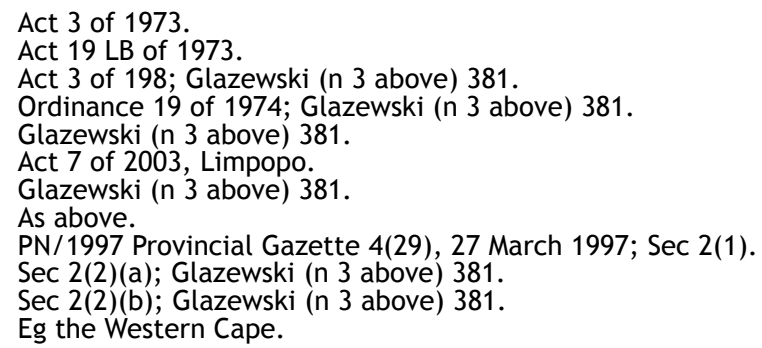


nature conservation in general. ${ }^{145}$ Other legislation still applicable in this province includes the Bophuthatswana Nature Conservation Act $^{146}$ and the Protected Areas Act (Bophuthatswana). ${ }^{147}$

\subsection{Western Cape}

The Western Cape Province has followed the trend set by KwaZuluNatal, Mpumalanga and the North West Province, and implemented the Western Cape Nature Conservation Board Act. ${ }^{148}$ The objects of the Board are 'to promote and ensure conservation and related matters in the Province.' 149 'Nature conservation' is defined in the Act as: 150

the conservation naturally occurring ecological systems and the sustainable utilisation of indigenous plants and animals and the promotion and maintenance of biological diversity, within these systems due regard to the need to preserve objects of geological, archaeological, historical, ethnological, educational, oceanographic or scientific interest.

It is clear from this that the Board in the Western Cape will not assume environmental management functions and those functions will remain the competence of the Western Cape Department of Environmental Affairs, Culture and Sport. ${ }^{151}$ This could pose a problem as this department already has its hands full with the task of performing environmental impact assessment regulations as set out in Chapter 8 . Other legislation still in force in the Province includes the Nature Conservation and Environmental Conservation Ordinance, ${ }^{152}$ the Problem Animal Control Ordinance ${ }^{153}$ and the Kango Caves Ordinance. ${ }^{154}$

Glazewski (n 3 above) 381.

Act 3 of 1975, Bophuthatswana.

Act 24 of 1987, Bophuthatswana.

Act 15 of 1998, Western Cape; Provincial Gazette Extraordinary PN 709/1998, 30

December 1998, amended by Western Cape Nature Conservation Laws Amendment Act 3 of 2000, Provincial Gazette 5442, 24 March 2000.

Sec 3(a); Glazewski (n 3 above) 381.

Sec 1(x); Glazewski (n 3 above) 382.

Glazewski (n 3 above) 382.

Ordinance 19 of 1974.

Ordinance 26 of 1957

Ordinance 5 of 1971. 


\section{Other legislation relating to wild animals}

\subsection{Animals Protection Act ${ }^{155}$}

\subsubsection{Introduction}

The object of this Act is to prevent cruelty to animals as stated in the long title. ${ }^{156}$ This Act was promulgated with domestic animals in mind but with the definition of 'animal' so wide; its application includes wild animals, birds and reptiles. ${ }^{157}$ The definition states: ${ }^{158}$

animal means any equine, bovine, sheep, goat, pig, fowl, ostrich, dog, cat or other domestic animal or bird, or any wild animal, wild bird or reptile which is in captivity or under the control of any person.

The Minister of Justice used to administer the provisions of this Act but after 1997 the Minister of Agriculture and Land Affairs has taken over its administration. ${ }^{159}$ The Society for the Prevention of Cruelty to Animals plays an important and active role in monitoring and campaigning against the cruelty of animals. ${ }^{160}$

The most important provision in this Act prohibits any type of maltreatment of animals and makes it a criminal offence subject to a fine and/or imprisonment. ${ }^{161}$ Therefore, if anybody overloads, neglects, confines any animal unnecessarily or starves or underfeeds the animal, that person would be guilty of an offence and be subject to a penalty. 162

\subsubsection{Implementation and enforcement}

The responsibility for the activities which amount to an offence as mentioned above can be imputed to the owner of the animal in question. ${ }^{163}$ The section states:

for the purposes of subsection (1), the owner of any animal shall be deemed to have permitted or procured the commission or omission of any act in relation to that animal if by the exercise of reasonable care and supervision in respect of that animal he could have prevented the commission or omission of such act. ${ }^{164}$

As above.

Sec 1; Glazewski (n 3 above) 382.

Glazewski (n 3 above) 382.

See Society for the Prevention of Cruelty to Animals, Standerton $v$ Nel and others 19884 SA 42 (W); Glazewski (n 3 above) 382.

161 Sec 2(1); Glazewski (n 3 above) 382.

162 Sec 2(a)-(s) set out the offences in detail; Glazewski (n 3 above) 382.

163 Glazewski (n 3 above) 382.

164 Sec 2(2)(2); Glazewski (n 3 above) 382. 
The court is also, in addition to the criminal sanction, empowered to grant an order for damages not exceeding the amount of R5000 where a person has, as a result of such an offence, incurred expenses like veterinary costs, food, transport, etc. ${ }^{165}$

Lastly, the Constitution has also relaxed locus standi requirements and it is now permitted for a litigant to bring an action on someone else's behalf and even if it in the public interest. ${ }^{166}$ The Societies for the Prevention of Cruelty to Animals Act ${ }^{167}$ recognises the legal standing of the SPCA in any event. ${ }^{168}$

\section{Community based wildlife conservation in South Africa ${ }^{169}$}

\subsection{General remarks}

As mentioned in above in this chapter, South Africa does not have a single coherent body of laws with regard to the environment's use and protection. ${ }^{170}$ The laws that do exist have been enacted by the national legislature, the various provincial legislatures and local authorities. ${ }^{171}$ As stated by Fuggle and Rabie ${ }^{172}$

(A) prominent feature of South African environmental legislation is its diffuse nature, with provisions being contained in an extremely wide variety of parliamentary Acts, provincial ordinances, local by-laws and ministerial regulations.

This provides for a very unsatisfactory situation because the laws protecting wildlife is extremely fragmented. ${ }^{173}$ The primary control over nature conservation is in the hands of the various provinces and the issue is dealt with through the respective provinces' ordinances. ${ }^{174} \mathrm{~A}$ result of this approach is that wildlife generally does not get protection outside of protected areas, ${ }^{175}$ and if they do it is usually limited. ${ }^{176}$ There is a clear lack of effective and integrated management and the reason for this is because the responsibility for

Sec 4(1); Glazewski (n 3 above) 382.

Sec 38 of the Constitution of the Republic of South Africa, 1996; s 4(1); Glazewski (n 3 above) 383. Act 169 of 1993.

Sec 4(1); Glazewski (n 3 above) 383.

R Summers in G Bradfield (ed) et al Environmental Justice and the Legal Process (1999) 188.

Summers (n 170 above) 203.

As above.

Fuggle \& Rabie (eds) Environmental Management in South Africa 1996; Summers (n 172 above) 203.

Summers (n 172 above) 203.

As above.

Eg national parks, nature reserves, private game reserves and state forests. Summers (n 172 above) 203-204. 
natural resource management is shared by too many different national and provincial ministries and it is, therefore, unclear where to place the blame should certain tasks not be completed. ${ }^{177}$

This means that the institutional framework, as well as the legal system, generally fail to facilitate integrated approaches to land use, including the protection of the natural environment. The Physical Planning Act 125 of 1991, the Environmental Conservation Act and the Conservation of Agricultural Resources Act assume integration of environmental management in land use planning. However, at the administrative level, environmental management practises remain sectoral and fragmented. ${ }^{178}$

There has been a growing acceptance in the South African community that when policy is formulated regarding conservation issues, the decision-makers need to take the greater socio-economic context into account. ${ }^{179}$ Part of this would be that rural communities have an important role to play in the future of wildlife conservation in South Africa. ${ }^{180}$ This is illustrated by the following paragraph: ${ }^{181}$

For any legal dispensation to be effective and enduring, it should be socially and economically relevant. South Africa is a developing country and its wildlife law must respond appropriately to its development needs and the apparent dilemma of conserving natural resources while at the same time recognising the subsistence needs of indigenous people. It is essential that the last remnants of our wildlife and its habitat be legally protected, but the laws must be so formulated and applied as to permit of controlled taking on a sustained-yield basis, particularly in those areas where the traditional way of life depends upon access to flora and fauna for food, fuel, medicine and building materials. Local people should be permitted controlled access to natural resources within such areas, or defined buffer zones, consistent with their traditional harvesting practises. Irrespective of theoretical or philosophical commitments the reality is that South African wildlife law must be human-oriented, otherwise it will not be effective. There should be provision, as a matter of law and not of administrative policy, for local participation in the protection of wildlife and natural areas, the determination of reserve boundaries and the preparation of management plans, and in the economic benefits derived from these resources.

Ridl adds to this, that South Africa should develop 'its own unique character in its law, one that accommodates the diversity of land and its people.' 182

Summers (n 172 above) 204.

White paper on South African Land Policy, April 199724.

Summers (n 172 above) 204.

As above.

Bothma \& Glavovic 'Wild Animals' in Fuggle \& Rabie (n 180 above) 258; Summers (n 173 above) 204.

JA Ridl An Environmental Law Trilogy 1992 16-17; Summers (n 173 above) 204. 


\subsection{Recent policy formulation and legislative developments}

\subsubsection{Sustainable use and conservation of biodiversity}

The Environmental Conservation $\mathrm{Act}^{183}$ is currently the most important piece of legislation regarding environmental conservation because it provides for, inter alia, the determination of policy with regard to environmental management. ${ }^{184}$ It states that policy must be developed and implemented with regard to 'the promotion of sustainable utilisation of species and ecosystems and the effective application and re-use of natural resources, 185 this clearly shows willingness on the part of the government and legislature to give effect to controlled utilisation of the environment. ${ }^{186}$ The Act also specifically provides, in the classification of protected areas, for the establishment of sustainable use areas as one of the possible six types of protected areas. ${ }^{187}$ In this regard Fuggle and Rabie state that: ${ }^{188}$

development of nature conservation and specifically the establishment and management of protected areas were to be preserved solely as sacrosanct wildlife sanctuaries. The accommodation of the lifestyles, aspirations and needs of local communities as part of the overall conservation ethic had become a globally accepted principle.

One can, therefore clearly see that South Africa is on its way to developing a sound and comprehensive policy regarding conservation, environmental management and the sustained use of natural resources. ${ }^{189}$ In addition to this, South Africa has also become a party to the Convention on Biological Diversity which came into force in December 1993 and its objects include: the conservation of biodiversity, the sustainable use of biological resources and the fair and equitable sharing of benefits arising from the use of genetic resources. ${ }^{190}$ Because South Africa is part of this Convention, it has an obligation to develop national strategies and policies in order to give effect to these objectives. ${ }^{191}$

In the national context, the Constitution must also be considered when formulating policy regarding conservation. ${ }^{192}$ It states in the Bill of Rights that every person has the right: ${ }^{193}$

84 Summers (n 172 above) 205.

185 Rabie 'Environmental Conservation' 1996 Law of South Africa 143; Summers (n 172 above) p205.

186 Summers ( 172 above) 205.

187 Sec 2(1); Summers (n 173 above) 205.

188 Fuggle \& Rabie (n 180 above) p120; Summers (n 173 above) 205.

189 Summers (n 172 above) 205.

190 White paper on the Conservation and Sustainable Use of South Africa's Biological Diversity, May 1997 p11; Summers (n 172 above) 205.

191 Summers (n 172 above) 205.

192 Summers (n 172 above) 205.

193 Sec 24, Constitution of the Republic of South Africa, 1996. 
(a) to an environment that is not harmful to their health or well-being; and

(b) to have the environment protected, for the benefit of present and future generations, through reasonable legislative and other measures that:

(i) prevent pollution and ecological degradation;

(ii) promote conservation; and

(iii) secure ecological sustainable development and use of natural resources while promoting justifiable economic and social development.

The White Paper on the Conservation and Sustainable Use of South Africa's Biological Diversity emerged out of this context. ${ }^{194}$ Chapter 2 of this paper states that one of the guiding principles is sustainable use of natural resources. ${ }^{195}$ Probably even more important than this is Policy objective 1.4 which gives recognition to the fact that natural resources outside of protected areas must also be conserved while also considering promotion of sustainable development. ${ }^{196}$ One of the potential strategies that the government is considering in order to give recognition to this policy is community-based wildlife management schemes. ${ }^{197}$ The government also explicitly stated that is will 'support the development of community-based wildlife management initiatives as part of a broader set of approaches to landuse planning and developing local sustainable development strategies. ${ }^{19}$

Added to this, government states that it will promote community participation in management of resources, both within and outside protected areas. ${ }^{199}$ The department whose role it is to formulate such policy is the Department of Environmental Affairs and Tourism (DEAT). ${ }^{200}$ Provincial government and conservation agencies are also key players in this process. ${ }^{201}$ Probably the most important roleplayers in the conservation and sustainable utilisation are the communities themselves. ${ }^{202}$ Inclusivity and participation are two of the broad principles that could be the foundation for the development of sound policy on community-based conservation. ${ }^{203}$

An important legislative development was the law commission on the Loss of Ownership of Game and the later promulgation of the

194 Summers (n 172 above) 206.

195 White paper (n 193 above) 21.

196 Summers (n 172 above) 206.

197 As above.

198 White paper (n 193 above) 34.

199 Summers (n 172 above) 206.

200 As above.

201 As above.

202 'In some instances, communities will play an important role in managing and using resources to ensure their conservation and sustainable use' White paper (n 198 above); Summers (n 172 above) 206.

203 Summers (n 172 above) 206. 
Game Theft Act ${ }^{204}$ by considering the report of the law commission. The Act can be seen as an acknowledgement of the commercial importance of wildlife regarding privately owned commercial game farms. ${ }^{205}$ Whether the legislature will ever go so far as to give ownership over natural resources to rural communities is yet to be seen, nevertheless, the basis upon which legislative development may be made in this regard is there in the waiting. ${ }^{206}$

\section{Conclusion}

If one considers the material law protection of wild animals and other living resources one could, with confidence, say that there does exist sufficient law to protect South Africa's resources. The problem is that the legislation and ordinances are extremely fragmented, so much so that it is often difficult to make sense of all the different laws applying to a specific area or jurisdiction.

A possible solution to this problem is a complete revamp of the nature conservation laws in South Africa from top to bottom, starting with enabling national legislation and proceeding to the provinces that then make legislation in accordance with their personal needs which complies with the national laws.

A final submission as a solution to the enforcement problem, as stated by Summers, ${ }^{207}$ is to involve the surrounding communities by way of education of the ecosystems and interdependent species in the area, assisting in the protection thereof and, should a profit be derived from the sustainable use and exploitation thereof, having the community share in that as well. 



\title{
RACE AND RAC(IAL)ISM, THE POLITICS OF PEACE AND FRIENDSHIP IN A LIBERAL CONSTITUTION
}

\section{NEW REFLECTIONS OR OLD WINE IN NEW BOTTLES? A CRITICAL ANALYSIS}

\author{
by J Modiri*
}

\section{Introduction}

b is for black

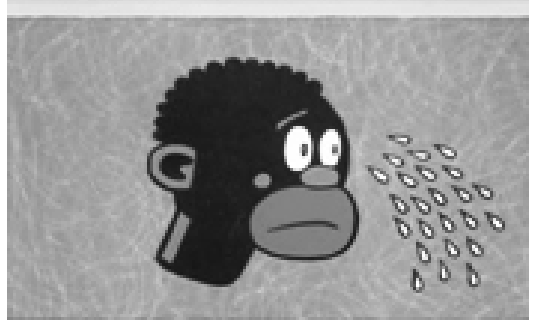

black adj opposite of white. dirty. messy. without light dark. illegal dim. smuggled sombre disasterour, dismal. obscure. sullen bad-tempered angry. horrible. grotesque malignant. unlucky, unhappy, depressed.

SSURECE: CHAMBEES \& OXFOND DICTIONARIES w is for white

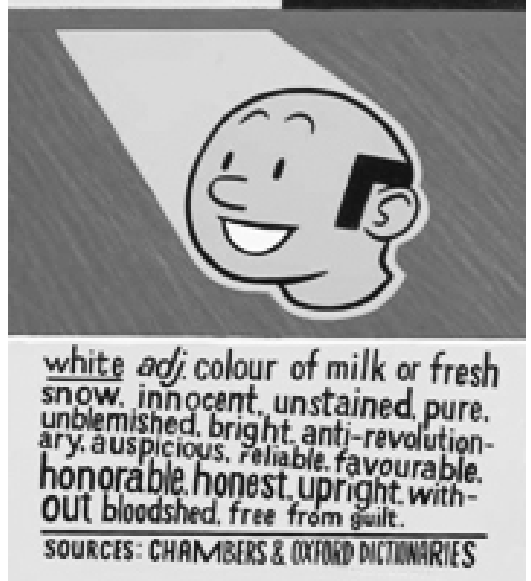

Figure 1 \& 2: Lithographs by Anton Kannemeyer (bitterkomix) ${ }^{1}$

The context of this article is a two-part investigative documentary on 'race' as an enduring fault line in South African politics on etv's 3rd

* Joel S M Modiri, first year LLB student, University of Pretoria. My thanks to Professors Anton Kok, Duard Kleyn and Karin van Marle for incisive comments and illuminating discussions. I must also thank Ms Lorette Arendse for inputs and editorial suggestions to the final draft of this article.

1 In these prints Anton Kannemeyer has focused on images from his Alphabet of Democracy series. 
degree $(2010)^{2}$ programme as well as a true-life drama, For One Night $(2006)^{3}$ which explores a 30-year old 'tradition' of racially segregated school dances in southern American states. The events detailed in both shows resonate strongly with the essence of this article in that they both publicly engage with and challenge pre-existing ideas about race and racialism and depict ordinary citizens having to be confronted by the ongoing uneasiness of race in their daily lives. On $3 r d$ degree, students at University of the Free State (UFS), spoke honestly about the challenges of racism they face at UFS, on campus and in the residences. On For One Night, conservative white families had to come to terms with the possibility of their children mingling with their black counterparts at the traditionally segregated school dance for the first time in 30 years.

The wider concern of all of this is firstly, to question whether and why 'race' still exists as a major force of South African identity 17 years after legislated apartheid came to an end and then to explore the role of law in our 'race' and 'colour' lives. With reference to the Truth and Reconciliation Commission (TRC) and the emergence of modern forms of racism, questions will be raised on whether the law has been able to deliver authentic transformation, substantive equality and social justice. This article will also follow a critical analysis of notions of 'reconciliation' and 'victimhood' which are central to dialogue on race in South Africa. Against this background, I will reflect on Hannah Arendt's theories on the 'banality of evil' and her subsequent call for deliberate thought and action in order for people, black and white, to 'appear to each other...' ${ }^{4}$

Following this, central focus will be given to the possibilities of a politics of peace and friendship in South Africa - one that goes beyond the racial and transcends the current hopes of a colour-blind society. ${ }^{5}$ In order to explain how we could achieve such a politics, I turn to Van Marle's notion of 'refusal' as a way to reflect on ethics and politics in post-Apartheid South Africa. ${ }^{6}$ This 'ethics of refusal'

2 Produced and hosted by award-winning journalist Debora Patta. Part 1 (25 May 2010) deals with white South Africans and part 2 (1 June 2010) deals with young South Africans. The documentary vividly crystallises the South African experience when it comes to race and reconciliation 16 years since the advent of our new democracy. See in general D Herwitz Race and reconciliation: essays on the New South Africa (2003).

3 Directed by Ernest Dickerson. 'A black southern high school senior becomes a catalyst for a historic change in tradition. She fights to desegregate her high school prom.'

$4 \quad \mathrm{~K}$ van Marle 'On loneliness and the value of slow reflection' (2009) 30 Verbum et Ecclesia 338.

5 See N Gotanda 'A Critique of our "Constitution is Colour-Blind"' (1991) 43 Stanford LR 1 .

6 K van Marle 'Laughter, refusal, friendship: thoughts on a "jurisprudence of generosity"' (2007) 18 Stellenbosch Law Review 194. See S Woolman 'On rights, rules and relationships: a reply to Van Marle's 'jurisprudence of generosity' (2007) 18 Stellenbosch Law Review 508. 
will be proposed as an appropriate response to the gaps in the current discourse on race in South Africa. Writing elsewhere, Van Marle also offers a suggestive understanding of the role of the South African community in fundamentally altering race relations in her reading of 'loneliness' and 'solitude' as forms of political action. I will then consider the role of the Constitution and fit into place, the concepts of 'transformative constitutionalism' and 'memorial constitutionalism'. In conclusion, it will be argued that ubuntu - or an 'ethics of humanity' - should be a flagship feature of a politics of peace and friendship in South African society.

This article attempts to conceive of 'race' as a critical project through which dominant assumptions about race and apartheid are questioned and to challenge the contradictions inherent in the dichotomies of race/redress, race/equality, and race/class. In this way, the space for critique and dissent is widened and the role of law in helping South Africans to live differently under law after apartheid is contemplated. A critical analysis of race in the context of law, history and political ethics also makes room for the detection and elimination of emerging subtle forms of modern racism in society. Throughout all of these reflections and contemplations, there will be no attempts to give solid and conclusive answers - not least because there are no such answers to give but because any attempts to answer or solve might possibly end the debate; stifle urgent and pressing issues which lay beneath the soil of racial politics and close the space for the engagement of clashing values, of plural minds and of the difficult discussions that still need to take place.

\section{Race and rac(ial)ism}

It is common cause that racism began long before apartheid was institutionalised by the National Party (NP) in $1948 .^{7}$ Throughout its many guises in history - from slavery in the $1600 \mathrm{~s}-1800 \mathrm{~s}, 8$ to white supremacy, to segregation - it was portrayed as the need to separate the different ethnic groups and to give each race their own spaces to preserve their heritage and to develop political and administrative governing systems that were congruent with their cultures, traditions and identities. Notwithstanding this, racial segregation has always been accompanied by supremacist tendencies of racial violence, state repression and prejudice as well as economic deprivation. One could very easily criticise law and legal institutions for its culpability throughout this part of history. Through law, colonialism distorted the cultures and identities of black people. Colonialists seized the land

7 H Giliomee \& B Mbenga New history of South Africa (2007) 306. See N Rubin 'Law, race and colour in South Africa' (1974) 3 A Journal of Opinion 6.

8 http://africanhistory.about.com./od/slaveryinsouthafric1Slavery_in_South_ Africa.htm (accessed 11 September 2010). 
(which they termed as terrae nulliae) as well as the resources of indigenous African societies whom they considered to be uncivilised. ${ }^{9}$ The law aided the continued subjugation of black people into the 20th century through substandard Bantu education, humiliating pass laws and extreme forms of political violence against black people. It is in this kind of law and in this particular history that we can find the birth and continued existence of racism. It also follows therefore that the end of apartheid in 1994 or perhaps in 1990 when FW de Klerk announced the unbanning of the ANC, PAC and other anti-apartheid organisations, did not, or rather should not have symbolised the end of racism and racial politicking. However this was not the case. A formal change in the legal and political system to many in the country meant, albeit erroneously, that racism was a relic of the past and South Africans could somehow 'move on'. This false belief, further compounded by the 'rainbow nation' motif of the mid-1990s and the euphoria of the 1995 Rugby World Cup and 1996 African Cup of Nations, created the impression that a new South Africa had been born and that racial animosity and all the concomitant problems of oppression, discrimination, victimisation and marginalisation had come to an end. But this was not to be.

The TRC, set up in 1995 in terms of the Promotion of National Unity and Reconciliation Act ${ }^{10}$ was a spectre of how racially divided the South African landscape had become because of and after apartheid. The TRC was divided into three committees. ${ }^{11}$ The Committee on Human Rights Violations (HRV) was tasked with investigating the human rights abuses that took place between 1 March 1960 and 10 May 1994, testimonies and statements of unspeakable horrors surfaced and old wounds were torn open as families heard - in graphic detail - how their loved ones were tortured, killed, maimed and violated. The Reparations and Rehabilitation (R\&R) Committee was empowered to provide victim support to ensure that the TRC process protected the dignity of the victims and to formulate policy proposals on the rehabilitation and healing of survivors. The compensation from the President's Fund and counselling services to survivors was the only visible result of the work of the R\&R Committee with little focus - in practice - being placed on re-engineering South African societal relations and reconciling ordinary citizens. The third committee and perhaps the most controversial source of the unresolved racial divisions that pervade our body politic, was the Amnesty Committee (AC) whose function, broadly defined, was to grant amnesty to perpetrators of apartheidera violations, which included murder, abduction and torture. All that

PhJ Thomas, CG Van der Merwe \& BC Stoop Historical foundations of South African Private Law 2ed (2008) 9. See also A Rycroft Race and the law in South Africa (1987) xiii - Xx

10 Act 34 of 1995.

11 http://www.justice.gov.za/trc/trccom.html (accessed 9 June 2010). 
was required from these individuals was a full disclosure of the facts related to the violation in question and the showing of 'remorse' whereupon they would be exempted from any future prosecution for those crimes.

The furore about the Amnesty Committee and the nature of its powers led to AZAPO $\vee$ TRC $(A Z A P O ~ I) .{ }^{12}$ The Azanian People's Organisation (AZAPO) and the families of Steve Biko, Victoria and Griffiths Mxenge and Fabian Ribeiro challenged the constitutionality of the TRC Amnesty Committee on the basis that it violated the constitutional right of access to justice and to have disputes settled in court. The high court rejected the challenge and the matter was then taken to the Constitutional Court (itself a new construction of post-apartheid ambition) in AZAPO $v$ President of the Republic of South Africa (AZAPO II). ${ }^{13}$ In AZAPO II, the court denied the appeal on the basis that 'truth' was necessary in order to enable reconciliation and to prevent the repetition of past injustices. For this 'truth' about past abuses to come out, amnesty had to be granted to those responsible, especially considering the transition in South Africa. ${ }^{14}$ Since AZAPO II, legions of academics, researchers and commentators have spoken unfavourably of the TRC. One such researcher, Nahla Valji, exposes the 'denial of the politicisation of race and the fundamental racialisation of politics that characterised apartheid' in the work of the TRC. She notes how '[c]ommissioners visibly steered participants away from discussing race' and also how ' $[\mathrm{t}]$ he final TRC report itself mentions racism fleetingly.' ${ }^{15}$ The failure of the TRC to engage with the historical legacy of racism has led to the easy and misleading claim by former beneficiaries of apartheid that what happened in the TRC is adequate transformation. This technocratic approach to reconciliation produced the odd rhetoric that was employed by the Mbeki government and 'big business' to oppose a lawsuit against multinational corporations which benefitted unjustly from the oppression of blacks during apartheid. ${ }^{16}$

The ongoing debate on race, racism and racialism in South Africa stands in this framework. Racism and racial thinking was created by conditions that were social, political, legal and economic in nature. The solution must therefore be as multifaceted as the problem. It is here where 'victimhood' or the definition of who falls under the

19964 SA 562 (C).

19964 SA 671 (CC).

See $K$ van Marle and W le Roux 'The unmentioned names that remain' in Van Marle \& Le Roux (eds) Law, memory and the legacy of Apartheid: ten years after AZAPO (2007) vi.

$15 \mathrm{~N}$ Valji 'Race and reconciliation in a post-TRC South Africa' available at http:// www.csvr.org.za/wits/papers/papnv3.htm (accessed 11 September 2010).

16 http://www.mg.co.za/article/2010-01-05-daimlers-economic-threat (accessed 1 October 2010). 
category of 'victim' or 'survivor' becomes pertinent. Madlingozi ${ }^{17}$ argues that the TRC process classified 'victims' quite narrowly as only those who, in the opinion of the HRV Committee, had suffered a gross violation of human rights in the form of murder, abduction, torture or severe abuse. He then relies on Borer who argues that '[ $\mathrm{t}$ ] he victimisation of one individual clearly has ripple effects on families and communities and several indirect victims can be identified'.18 Madlingozi includes families (of primary victims) as secondary victims who can in fact become primary victims in cases where they themselves were harassed and brutalised by security forces in order to extract information from them. Another tier of victims that Madlingozi identifies are those people who were casualties in the state-engineered 'black-on-black' inter-community violence as well as whole communities who 'suffered under apartheid policies of forced removal, the migrant labour system, racial classification [and] job reservation'. 19 The notion of 'victimhood' played a significant role in dividing South Africans because those who benefitted from post-apartheid reparations, special pensions and other Affirmative Action (AA) and Broad-Based Black Economic Empowerment (BBBEE) policies - the 'good victims' - found it easy to embrace the reconciliatory tone of the TRC and the spirit of 'Madiba Magic' while the 'bad victims' were left in the doldrums of the South African economy - jobless, poor and illiterate - to die alone in their social misery.

Racial prejudice is therefore a problem and the eradication thereof has to do with the eradication of deeply entrenched power relations and a change in the living conditions of South Africans in order for them to enjoy the freedom that could liberate them from the baggage of the past.

However, even attempts to reverse the racial polarisation that pervade South Africa also require that we reckon with the changing contours and dynamics of racism. Mosikatsana, in contemplating the adoption of critical race theory in South African legal discourse argues that '[t]he deinstitutionalisation of racism in South Africa by abolishing racist laws ushered in a new phenomenon referred to as modern racism. This form of racism has distanced itself from ideas of biological inferiority by linking race with trumped-up concepts such as 'culture', 'the maintenance of standards' and 'tradition'. ${ }^{20}$ The most

T Madlingozi 'Good victim, bad victim: apartheid's beneficiaries, victims and the struggle for social justice' in Van Marle and Le Roux (eds) Law, memory and the legacy of Apartheid: Ten Years After AZAPO (2007) 109 - 110.

18 T Borer 'A taxonomy of victims and perpetrators: human rights and reconciliation in South Africa' (2005) Human Rights Quarterly 1088.

19 Madlingozi (n 17 above) 110.

20 T Mosikatsana 'Critical Race Theory' in C Roederer \& D Moellendorf (eds) Jurisprudence (2004) 283. See also K van Marle 'Teaching critical race theory in South African universities/law faculties' (2001) 12 Stellenbosch Law Review 86. 
defining features of this new form of racism are (1) its lack of explicit reference to race and (2) the systemic exclusion of previously disadvantaged groups through the operation of structural power. ${ }^{21}$ These new subtle and cryptic forms of racism naturally pose problems for any strategies at alleviating racial inequality and discrimination. James and Lever note:

It seems fair to suggest that race-consciousness remains high in South Africa but that overt racism has declined considerably. There are continuing reports of rather anomic outbreaks of interpersonal violence, such as the shooting of a child by a white farmer early in 1998. This incident in turn had to be viewed against a spate of killings of white farm occupants that took on worrying dimensions in 1997. It is an open question to what extent high levels of crime (as in the farm killings) are in some sense racially based or at least racially justified in the minds of perpetrators. Similarly, the extent to which the economically dominant white section practices informal racial exclusion of an odious kind is not easy to gauge. 22

This illustrates that a more sustained engagement with the cultural patterns that have reproduced racial bias and racial prejudice in institutions of higher learning and the workplace, in the private sector, in schools, in integrated communities, in civic and political organisations and in the private sphere of friendships, clubs and romantic relationships discloses new possibilities for ' $r a c e$ as a radical analytical focus area for research and political project.'23

I will now turn to Hannah Arendt's thoughts on the 'banality of evil'. ${ }^{24}$ This is a notion that should be reflected on as the question of race and racialism in South Africa is considered. Like Arendt's contemplations on the Eichmann controversy, it is argued that when dealing with race, racism and racialism in South Africa we should be less concerned with political action and more with the faculties of judging and thinking. In this way racism, like evil, is correctly seen as a failure to exercise one's capacity of thinking, to self-reflect and to then use that self-reflection as the basis for personal judgment. ${ }^{25} \mathrm{Her}$ observations of Eichmann can be said of those who willingly served the apartheid regime and those who continue to perpetuate racist ideology and racial social thinking. These are not malicious bigots and unrepentant racists but rather victims of 'artificial reconciliation' and

See P Gilroy 'The end of anti-racism' in P Essed \& D Goldberg (eds) Race critical theories (2002) 253 - 258.

22 W James \& J Lever 'The second republic: race, inequality and democracy in South Africa' in CV Hamilton et al (ed) Beyond racism: race and inequality in Brazil, South Africa and the United States (2001) 51.

23 J Jansen 'The racial question and intellectual production in South Africa: A critical response to Ivan Evans'(1991) 12 Perspectives in Education 107-110 .

$24 \mathrm{H}$ Arendt Eichmann in Jerusalem: A report on the banality of evil (1963). See also L Le Roux 'Where does evil reside? a comparative study of Hannah Arendt and Antjie Krog' (2009) 3 Pretoria Student Law Review 84-99.

25 H Arendt 'Personal responsibility under dictatorship' in J Köhn (ed) Responsibility and judgment (2003) 23. 
innocuous individuals who operated thoughtlessly in the reality of the day. Because they had understood life as one in which the 'white man' was supreme they never had the chance to imagine the possibility of a black majority government and so carried out the order of the day with uncaring force and precision. The persistence of racism and racial paranoia (the fears about reverse-racism and about the 'white man' still oppressing blacks) should also be understood in that context. The banality of evil or the ordinariness of racism lies in the inability of South Africans to engage in internal dialogue. Consequently, people become unaware of the nature of their deeds and thoughts and are accordingly isolated by their self-evident conceptions of South African life, which make them insensitive to the experiential standpoint of their victims or the targets of their racism. It is through Arendt's conception of an honest and self-reflective thinking that our actions might keep us from slipping into a passive acceptance of evil crimes and a tolerant acquiescence of the immorality and hatred that is racism.

\section{The politics of peace and friendship}

In the preceding section, it was lamented that the 'rainbow nation' myth and the misdirected work of the TRC ${ }^{26}$ created the delusion in the South African community that 'we can now move on' and that we have been able to develop a cohesive national identity in South Africa. Consequently, in this section, more constructive criticism to the lofty ideals which the TRC and the 'rainbow nation' sought to - but failed to - achieve will be offered.

The starting point is Van Marle's thoughts on an ethics of refusal 27 which, following Arendt above, signals the start of more conscious thinking, introspection and action. Van Marle writes:

In South Africa it seems as if transformation, socio-economic reparation and other social problems like poverty, violence and disease are addressed mostly through law and human rights. But, as is often argued and exposed, law and human rights are lacking in the capacity to effect

See C Du Toit 'Diversity in a multicultural and polyethnic world: challenges and responses' (2004) 25 Verbum et Ecclesia 442 in which he argues that: 'The effect of the TRC hearings was perhaps to amplify black prejudice towards whites rather than to facilitate reconciliation. One can assume that the redistribution of power and the new Constitution helped to change people's prejudices. The government's efforts to instill a culture of dignity, to sell the idea of the rainbow nation, to approve the rights of minorities, to try and address the needs of the poor must also have impacted on prejudices. However, we have enough prejudice remaining to make it necessary that we remain very creative in solving our problems. The best way to change prejudice is by societal interaction and by exposure to difference.' 
real change. How can we find different ways to approach these issues in the face of the pervasiveness of law and human rights? ${ }^{28}$

Although, Van Marle conceived this 'ethics of refusal' in terms of rejecting patriarchy and the pervasive 'maleness' of law and society, it also provides a distinctly original ideological response to the polarised and antagonistic race relations in post-apartheid South Africa. Refusal marks a major shift in legal theory primarily because of its concern with the possibilities and simultaneous impossibilities of another political community, another law and a more egalitarian set of relationships between people. Situated within a post-apartheid context, refusal opens up legal discourses to social, political and ethical issues in people's day-to-day lives. Invoking the feminist slogan of 'the personal is the political', Van Marle places the accent on the agency of individuals to actively resist and reject certain archaic, essentialist and racist notions in the way they lead their lives. ${ }^{29}$

In the film, For One Night, black and white students, who attended the same classes, took part in the same sport activities jointly and had over the years built strong relationships beyond racial lines with one another, had to confront the idea that it was somehow correct and justifiable to separate them along racial lines on their prom night every year. It was when the lead character, Brianna McCalister, raised the obvious point that an ethics of refusal kicked in. The refusals illuminated by Brianna's actions, as well as the refusals which could be employed to resist racism and racial politics in South Africa, are:

- A refusal of the need to defend a narrow racial identity and a rejection of the 'us/them' dichotomy which is used to sustain segregation and discrimination. In the South African context, this also demands a dismissal of racial labels as 'apartheid-constructed identities'. 30

- A refusal to accept the recurrence of archaic and prejudiced cultures such as Afrikaner Nationalism and African Chauvinism which live through racially-exclusive organisations. ${ }^{31}$ In For One Night, the fact that a segregated school dance was a 30-year old tradition and the conservative call for 'keeping things as they are' were rejected by the seniors at Mercier High School when they ultimately did have a non-segregated dance.

- A refusal of the coercive pressures, calculated arguments and subtle dismissals which make it easier to tolerate racial divisions. When Brianna was told by the principal that part of being a 'good' valedictorian was being a good citizen, it was clear she was hinting to

Van Marle (n 4 above) 194.

See K van Marle 'The archaic structures of our desire' (2010) 25 SAPL/PR 195.

J Jansen 'Intellectuals under fire' (2004) 18 Critical Arts Journal 165.

See P De Vos http: / /www.constitutionalllyspeaking.co.za/158/ for a discussion on the constitutionality of racially-exclusive organisations (accessed 10 June 2010). 
Brianna that her continued call for a desegregated prom was disturbing those in power and that her hard-earned academic record could be on the line for this. By sustaining her activist call for one prom dance and not a black and white dance Brianna exemplifies this kind of refusal.

- A refusal to abide by the histories and heritages which symbolise racism. This also implies a refusal of the notion that cultural heritage and political history are 'set in stone' 'unchallengeable' and 'unchangeable'.

- A refusal of the perceptions, suspicions and subjectivities that fuel racial hatred and blow racial tensions out of proportion. This also means being vigilant and perhaps also sceptical of the media, politicians and even so-called analysts and intellectuals ${ }^{32}$ who often impose a narrative on South Africans which is inaccurate, negative and has the potential to send subliminal messages of racial divisions and disharmony among race groups in South Africa.

- But more generally, a refusal of tendencies and practices that exclude, divide (or separate) and indoctrinate. To quote Derrida, the refusal of racist ideology, 'requires that we change the most resistant, protected, archaic structures of our desire'. ${ }^{33}$

An ethics of refusal can be linked with terms such as 'resistance' and 'revolt' to indicate the need for a radical reformation of societal structures and a revisiting of law, its limits and its disconnect from justice and from politics. ${ }^{34}$ I will now turn to Van Marle's idea of 'solitude' over 'solidarity' as she interprets the relationship between Hannah Arendt and Mary McCarthy in order to understand how this politics of peace and friendship can be a part of the lived experience and how ordinary South Africans can each be a part of post-apartheid living. It should be clear that simply living in a time after apartheid does not imply post-apartheid living. As Van Marle mentions 'every day we still experience the legacy of apartheid on many levels',35 and so post-apartheid living 'indicates the attempts to deal with the past, the struggle of the becoming of something that could be named as 'post' but not 'past', at least by no means yet'. 36 It is argued therefore that while the legal and political institutions which created and fuelled racism have been 'transformed', the organic seed of racism still lives strongly in people and institutions that are still struggling to deal with the past.

For an example, see M Mbeki and J Rossouw 'Many nationalisms still cripple SA' Sunday Times (Review) 20 June 2010 6. See the response: M Blatchford 'Nonsense will bring disaster to SA' Sunday Times (Review) 27 June 2010.

33 J Derrida 'Opening plenary: Is feminist philosophy philosophy?' in Bianchi (ed) Is feminist philosophy philosophy? (1999) 27. See also J Derrida 'Racism's last word' (1985) 12 Critical Inquiry 291

34 K Van Marle 'Law's time, particularity and slowness' (2003) 19 SAJHR 239.

$35 \mathrm{~K}$ van Marle 'Jurisprudence, friendship and the university as heterogeneous public space’ (2010) 127 SALJ 628. 
This is why it is prudent to suggest 'solitude' as a way to resist racism. To start off, I would like to connect post-apartheid living with 'being alone' and on the 'same side'. ${ }^{37}$ Similar to Nelson's accounts of post-war movements calling for 'solidarity' and 'bonds of intimacy and group identification', the 'rainbow nation' motif and talks of a 'common national identity' made the same calls of South Africans. Considering the current political landscape and how it is mired with racial tension, Arendt and McCarthy's rejection of those stances and their choice of solitude and detachment over grandiose gestures of solidarity are appropriate to how society and law can deal with racial tension and general division in South Africa. The TRC is one of the many examples that amplify the horror of apartheid and like Arendt and MCCarthy, South Africans should choose 'toughness' as a response to the pain of that horror. Van Marle observes that:

Instead of being indifferent or callous, they wanted to face 'reality' without being consoled by intimacy, empathy or solidarity, which they regarded as having a potential 'anaesthetic' effect ... Arendt rejected notions of friendship that relied on intimacy as well as notions of national belonging, ideological partisanship and party politics. Nelson explains that, apart from solidarity's potential anaesthetic effect, it also holds the danger of coercion and exclusion. ${ }^{38}$

In a word, loneliness and detachment from the grand gestures and spectacle of the day could provide for what Mamdani calls 'social reconciliation' 39 -a project 'aimed at the ongoing construction of an active public sphere and at the becoming of a sociality that truly reflects plurality'. 40

Central to the becoming of a politics of peace and friendship in South African law and politics is the displacement of the pervasiveness of race-based identities through a radical understanding of difference. Botha laments the irony in how, despite the repeal of the Population Registration Act, ${ }^{41}$ racial categorisations created by the apartheid bureaucracy are being affirmed by the postapartheid government and still provide the blueprint for official definitions of race in state documents and legislation. ${ }^{42}$ In Botha's view, "continued state reliance on the racial categories of the apartheid era does little to challenge the crude, 'common-sense' view which equates race with biological attributes and uses it as a basis for making cultural generalisations'. ${ }^{43}$ Relying on MacDonald,

Van Marle (n 4 above) 90. See D Nelson The virtue of heartlessness: Mary McCarthy, Hannah Arendt, and the anaesthetics of empathy (2006).

Van Marle (n 4 above) 91.

M Mamdani 'When does reconciliation turn into a denial of justice?' in $\mathrm{S}$ Nolutshungu (ed) Memorial Lectures (1998) 1.

Van Marle (n 4 above) 93. See also K van Marle 'The Spectacle of Post-apartheid Constitutionalism' (2007) 16 Griffith LR 411 - 429.

30 of 1950.

H Botha 'Equality, plurality and structural power' (2009) 25 SAJHR 21.

As above 22 . 
Botha argues firstly for an alternative approach to broad-based economic redistribution which does not assume that all black people benefit when some of them join the capitalist elite. ${ }^{44}$ Secondly, he argues for a conception of difference which does not reduce individuals to social categories like race but takes their material circumstances and complex particularities into account. ${ }^{45}$ Botha calls for a constant questioning of the idea that reified racial categorisations are acceptable and immutable features of South African life. In this way, equality jurisprudence in South Africa is challenged to remedy the effects of past racism more effectively by responding to material disadvantage, structural inequality and social complexity.

\section{A liberal constitution}

The late Ettiene Murenik argued for the Constitution to serve as a 'bridge between an authoritarian past and a new democratic society'.46 This well-known bridge metaphor portrays the Constitution as a bridge between a past of deeply entrenched racism and gross violations of the dignity and rights of people and a future based on democracy and the protection of human rights and freedoms. This metaphor is taken up by another scholar, Karl Klare, who in a rightly in a rightly renowned essay coined the term 'transformative constitutionalism', which he defines as:

[A] long-term project constitutional enactment, interpretation, and enforcement committed (not in isolation, of course, but in a historical context of conducive political developments) to transforming a country's political and social institutions and power relationships in a democratic, participatory, and egalitarian direction. Transformative constitutionalism connotes an enterprise of inducing large-scale social change though nonviolent political processes grounded in law ... In the background is an idea of a highly egalitarian, caring, multi-cultural community, governed thorough participatory, democratic processes in both the polity and large portions of what we now call the 'private' sphere. 47

In the context of race, the noticeably transformative aspect of the Constitution is the inclusion in its founding provision of the ideal of 'non-racialism'. ${ }^{48}$ On this topic, Sharp describes non-racialism as 'an ideal of societal transformation' and a 'process' in which a commitment to eradicating racism and racial discrimination is

Botha (n 42 above)18.

46 E Mureinik 'A bridge to where? Introducing the interim Bill of Rights' (1994) 10 SAJHR 31.

47 K Klare 'Legal culture and transformative constitutionalism' (1998) 14 SAJHR 146.

48

Botha (n 42 above) 22. See M MacDonald Why race matters in South Africa (2006); O Dupper 'Affirmative Action: who, how and how long? (2008) 24 SAJHR 425.

$\mathrm{Sec} 1$ (b) of the Constitution of the Republic of Southern Africa, 1996. 
complemented by a comprehensive scheme to provide wide-ranging redress for the disadvantages and injustices that the majority of South Africans suffered in the past. He adds that "putting this ideal into practice will call not simply for a formal declaration of intent, as in the new constitution but also for the exercise of political will. 49

Recent judgements in the Constitutional Court point to the fact that 'non-racialism' does not suggest that South Africa is a colourblind or race-neutral society. In Minister of Finance $v$ Van Heerden, ${ }^{50}$ the Court expressly noted that 'we are far from having eradicated the vestiges of racial discrimination'. De Vos adds:

[O]ne can get to grips with the meaning of the constitutional text if one refers to the specific apartheid past to identify all the wicked attitudes and practices that existed before the commencement of the interim Constitution. It is thus only with reference to this shameful history that we can really understand what the text of the Constitution is trying to achieve. $^{51}$

As already mentioned, responding to racism through an 'ethics of refusal' or a 'politics of peace and friendship' urges a direct confrontation with 'the past'. This is captured by Klare's post-liberal reading of the Constitution as having 'historical self-consciousness'. ${ }^{2}$ This is where 'memorial constitutionalism' comes to the fore. Van Marle notes that:

Memorial constitutionalism, in contrast to monumental constitutionalism, holds the potential of being more aware of history, of the role of memory in post-apartheid law and, importantly, of being more aware of its own limits, its own impossibilities. ${ }^{33}$

In the context of race, 'memorial constitutionalism' could possibly provide the unlocking key to dismantling racism and racial living. An awareness of the terror and horror that plagued black communities, anti-apartheid activists and other victims of apartheid confirms the mantra that 'those who do not learn their history are condemned to repeat it' and can possibly lead to the paradigm shifts necessary to eschew the reproduction of inequality and the emerging forms of 'modern racism'. Memorial constitutionalism highlights the (utopian) promise of the Constitution because it focuses less on the experiences International Social Sciences Journal 243 African Constitution' (2000) 16 SAJHR 11.

Klare (n 47 above) 155. See also T Roux 'Transformative constitutionalism and the best interpretation of the South African Constitution: distinction without a difference' 2009 Stellenbosch LR 276; M Pieterse 'What do we mean when we talk about transformative constitutionalism' (2005) 20 SA Public Law 155; K van Marle 'Transformative Constitutionalism As/And Critique' (2009) 20 Stellenbosch Law Review 291.

53 Van Marle (n 4 above) 91. See also L du Plessis 'The South African constitution as memory and promise' (2000) 11 Stellenbosch Law Review 385. 
of apartheid agents and anti-apartheid activists and more on the lives of ordinary citizens. In this way, memorial approaches to the Constitution do not treat the evils of apartheid, socio-economic inequality and injustice as part of normal life and also give recognition to other diverse forms of disadvantage. Instead of 'monumental constitutionalism' and symbolic gestures of racial togetherness that claim South Africans are one big happy family, 'memorial constitutionalism' pursues a narrative of nation-building and inclusive citizenship which, unlike the TRC, does not negate the voices of the victims of racial violence while simultaneously retaining South African cultural diversity.

The paradox inherent in the notion of 'memorial constitutionalism' however is that in order to remedy the inequality and disadvantage created by racist apartheid laws, it will be necessary to invoke the broad racial labels, identities and categories which are themselves implicated in racial discrimination and prejudice. This paradox played itself out most notably in City Council of Pretoria $v$ Walker. ${ }^{54}$ In this case, the City Council of Pretoria was charging Black townships, as was the case during apartheid, based on a flat rate (because no meters were installed for measuring water) whereas the municipal charges for 'old city' residents were based on consumption. Walker (a white resident of old city Pretoria) considered the differential methods of levying and collecting service charges as unfair discrimination and consequently decided to pay the flat rate that was charged in the black townships. As a result, he fell in arrears for which the City Council of Pretoria sued him. After numerous decisions in the lower courts, the case ended up in the Constitutional Court which had to consider whether the system of charging different tariffs was a form of reverse discrimination in violation of the equality clause in the Interim Constitution. Langa DP, as he was known then, stated that the matter must be viewed in light of the fact that residents of Black townships were 'disproportionately poor and under-serviced'. 55 The Court held that while the practice of charging different fees did indeed amount to discrimination, it did not constitute unfair discrimination on the grounds of race. Sachs J pointed out that Walker had benefited from past discrimination against blacks and continued to enjoy the services of 'regular municipal services at all material times, ${ }^{, 56}$ which was not the case in Black townships. In Mosikatsana's view, the strategy adopted by Walker is a denial of racism by a white man who seeks to reverse charges of discrimination 'against a constituency which sought to alleviate social disparities which are a legacy of apartheid' ${ }^{57}$

19983 BCLR 257 (CC).

As above, para 269.

As above paras 103 - 105.

Mosikatsana (n 20 above) 289. 


\section{Conclusion}

Van Marle asks 'what entails research in post-apartheid jurisprudence?' ${ }^{58}$ At the very least I would like to respond that postapartheid jurisprudence should engage with race and rac(ial)ism, its causes and an investigation of possible ways to dismantle whatever foothold it still has in society. ${ }^{59}$ The advent of a new constitutional order in South Africa enables a transformative discourse on race, equality and freedom which could disturb South African interaction on issues of race, reparation and redress in such a way that Mamdani's notion of social reconciliation ${ }^{60}$ and Madlingozi's call for social justice $^{61}$ can possibly materialise. By 'disturbance' I mean a reawakening of the social conscience of people, an invocation of memorial constitutionalism and an active adoption of an ethics of refusal. I find disruption even more fitting considering the original missteps in the reconciliation agenda of the 1990s - the fact that we had a transition without meaningful transformation. Hannifin correctly describes disruption in this context as 'moments of interruption to expose the limits of legal discourse'.62

In the final analysis, only one thing should remain clear: postapartheid living, democracy, justice, diversity and their tensile interaction and overlap with law are complex projects which entail a critical engagement with dialogue, thought/thinking and more importantly, resolute action. This complexity should be evident in the use of multiple theories in this article. To drive this point home, I would like to think of ubuntu or an 'ethics of humanity' as a concept that encompasses an 'ethics of refusal', 'loneliness, detachment and solitude', a 'politics of peace and friendship', 'disturbance/ disruption' as well as 'thinking and judging'. For Cornell, ubuntu 'has a profound effect on both the institutions of law and the actual rules and processes that guide legal conflict'. ${ }^{63}$ Mokgoro $\mathrm{J}$ crystallises this idea quite vividly in the famous case which abolished the death penalty by arguing for an unashamedly ubuntu-based reading of the Constitution:

Ubuntu translates as humaneness. In its most fundamental sense, it translates as personhood and morality. Metaphorically, it expresses itself in umuntu ngumuntu ngabantu, describing the significance of group solidarity on survival issues so central to the survival of communities. While it envelops the key values of group solidarity, compassion,

58 Van Marle (n 40 above) 638.

59 See K Crenshaw et al (eds) Critical Race Theory (1995).

60 Mamdani (n 39 above).

61 Madlingozi (n 17 above) 107.

62 P Hannafin 'The writers refusal and the law's malady' (2004) 31 Journal of Law and Society 9.

63 D Cornell 'Ubuntu, pluralism and the responsibility of legal academics to the new South Africa' Inaugural Lecture, University of Cape Town, 10 September 2008. 
respect, human dignity, conformity to the basic norms and collective unity, in its fundamental sense, it denotes humanity and morality. Its spirit emphasises respect for human dignity, marking a shift from confrontation to conciliation. ${ }^{64}$

Her colleague Mahmood J offers an equally succinct description of the basic underpinnings of ubuntu jurisprudence in the Constitutional Court:

The need for ubuntu expresses the ethos of an instinctive capacity for and enjoyment of love towards our fellow men and women; the joy and fulfilment involved in recognising their innate humanity; the reciprocity this generates in interaction within the collective community; the richness of the creative emotions which it engenders and the moral energies it releases both in givers and the society which they serve and are served by. ${ }^{65}$

Because apartheid and racism, when conceived in terms of dignity, both had the effect of demoting the self-worth and intrinsic value of black people (and of white people in the process), ${ }^{66}$ I want to put forward ubuntu as a channel for moral repair and transracial unity in the becoming of a truly prosperous, non-sexist and non-racist society. Cornell describes ubuntu as an 'activist ethics of virtue'67 but the following statement by her shows very little tension between her description and mine:

Ubuntu requires us to come out of ourselves so as to realise the ethical quality of humanness. We are required to take that first ethical action without waiting for the other person to reciprocate. ubuntu then is not a contractual ethic. It is up to me. And, in a certain profound sense, humanity is a stake in my ethical action. Thus, if I relate to another person in a manner that lives up to ubuntu, then there is at least an ethical relationship that exists between us. Of course, if the two of us relate to others around us in a manner that lives up to an ethical understanding of humanness then we will have created an ethical community. ${ }^{68}$

It is this ethic of humanity that should be placed at the centre of postapartheid jurisprudence and it is through this ethic of humanity that the roots of racism could be problematised and challenged. As Kennedy puts it, '[w]e need to be able to talk about the political and cultural relations of the various groups that compose our society without falling into racialism, essentialism, or a concept of a 'nation'

64 S v Makwanyane 19953 SA 391 (CC) ; 19956 BCLR 665 para 307. See also Y Mokgoro 'Ubuntu and the law in South Africa' (1998) 4 Buffalo Human Rights LR 15.

65 As above, para 263.

66 See Art 1 of the UN Declaration on the Elimination of All Forms of Racial Discrimination (1963): '[d] iscrimination between human beings on the ground of race, colour or ethnic origin is an offence to human dignity.'

67 Cornell (n 63 above) 7.

68 Cornell ( $\mathrm{n} 63$ above) 6. See also D Cornell \& $\mathrm{K}$ van Marle 'Exploring ubuntu: tentative reflections' 2005 African Human Rights LJ 195; D Cornell 'A Call for a nuanced jurisprudence' (2004) 19 SA Public Law 661. 
tied to sovereignty' ${ }^{69}$ Racism and racial living has been a thorny issue in discourses on justice, democracy and law. These are deeply entrenched forms of being and living and it is only through a change in the core values of South Africans and the crafting of a politics that is strongly imbued with peace and friendship that we can hope to dislocate it. The transition from authoritarianism and civil conflict to a democratic order recalls a life of 'solitude' and interpretation of law and memory that takes into account the concrete experiences of victims of apartheid. The notion of ubuntu discloses possibilities for the creation of an ethical non-racial community animated by a refusal of past practices of discrimination and hatred. But as is also evident in the closing lines of the movie, For One Night, 'transformation has no beginning and end, but is a continuous process" 70 and so the same is to be said of the challenges of modern racism that now face the country:

The following year, the committee once again, invited everyone, black and white, to the same prom. A group of white students, however, decided to go back to the 'tradition' of two separate parties. Two steps forward, one step back ... Crenshaw et al (n 65 above) 159. See also D Kennedy Sexy Dressing Etc: Essays on the Power and Politics of Cultural Identity (1993) 34.

$70 \mathrm{~K}$ van Marle \& D Brand 'Ten thoughts on transformation' in Visser \& Heyns (eds) Transformation and the Faculty of Law, University of Pretoria (2007) 55. 



\section{A CALL FOR A DIFFERENCE IN TREATMENT BETWEEN CHILD AND ADULT OFFENDERS IN THE SOUTH AFRICAN PAROLE SYSTEM: AN INTERNATIONAL LAW PERSPECTIVE}

by I Gueorguieva*

\section{Introduction}

Internationally, parole is recognised and accepted ${ }^{1}$ as a means of the conditional release of a sentenced offender from a correctional centre into the community, before the expiration of the judicially imposed sentence of such offender. ${ }^{2}$ The functions of the placement on parole of the offender, which associate with the offender, include the rehabilitation of the offender and his reintegration into the community, ${ }^{3}$ as well as his restitution (e.g. in the form of symbolic restitution or community service). ${ }^{4}$ In Correctional Services authorities, parole acts occur to relieve prison overcrowding, encourage good behaviour within correctional facilities and to save costs related to imprisonment without negating the benefits of continued supervision and control. ${ }^{5}$

In South Africa, parole is predominantly governed by the Correctional Services Act 111 of 1998 (as amended) or, more particularly chapter IV (dealing with sentenced offenders), chapter VI (community corrections) and chapter VII (release from correctional centre and placement under correctional supervision and on day parole and parole). The provisions of chapter IV came into operation on 31 July 2004, whilst those of chapters V and VI came into operation on 1 October $2004 .{ }^{6}$ In addition, the provisions of the Correctional Services B-Order, Sub-Order 1, Incarceration Administration (hereinafter referred to as the Parole Manual) go a long way in clarifying and expanding on provisions in the Correctional Services Act, as well as indicating the practice and policy of the various

* Ina Gueorguieva, final year LLB student, University of Pretoria.

CML Louw 'The Parole Process from a South African Perspective' unpublished LLM thesis, University of South Africa, 2008375.

2 CH Cilliers 'New horizons for parole application in South Africa' (2006) 19(3) Acta Criminologica $i$.

Louw (n 1 above).

Louw (n 1 above) 38-39.

Louw (n 1 above) 40-42.

Proclamation R38, 2004 published in Government Gazette 26626, 30 July 2004. 
functionaries involved in the parole system. Section 28(1)(g) of the Constitution of the Republic of South Africa, 1996 (Constitution), on the other hand, provides that a child has the right not to be detained except as a measure of last resort and then only for the shortest appropriate period. Section 28(2) further provides that a child's best interests are of paramount importance in every matter concerning the child.

The question can then be raised: what effect do the above provisions have on the parole consideration of child offenders? Additionally, one can ask whether there is sufficient justification for a difference in parole treatment between child and adult offenders.

In order to answer the above questions, and to determine the additional issue of whether the South African parole system succeeds in measuring up to both international standards as well as its own constitutionally and legislatively entrenched aims, the provisions of several international instruments will be consulted and evaluated. This is desirable in view of the fact that the Constitution clearly provides in section 39(1)(b) that when interpreting the Bill of Rights a court, tribunal, or forum must, inter alia, consider international law. In other words, international norms and standards may have persuasive or even decisive value in court.

Before this is done, however, it will first be determined whether there is in fact a difference in treatment between children and adults within the South African parole system.

It should be noted at this stage that the Department of Correctional Services employee figures for 2005 indicated that there was one social worker available per 595 offenders, and 1 psychologist per 11223 offenders. ${ }^{7}$ This factor (combined with prison overcrowding) diminishes efforts to rehabilitate offenders. ${ }^{8}$ These professional persons are involved in assessing offenders, monitoring their mental development etc. ${ }^{9}$ They also provide insight to the Case Management Committee (CMC), which is responsible for compiling and submitting offender reports to the Correctional Supervision and Parole Board (CSPB). These reports inevitably influence the Board's decision as to whether or not an offender should be placed on parole. In other words, a shortage of psychologists and social workers diminishes the powers of the CMC, (and thus the CSPB and other functionaries) to properly consider an offender for parole as all the necessary information may not be before such authorities. 


\section{Differences in treatment between adults and children in the South African parole system}

The youth of an offender, at common law, has always been regarded as a mitigating factor in sentencing. ${ }^{10}$ There is also support for the proposition that age is a factor in parole placement consideration; Girdini has stated that '[s]tatistics have shown that age at the time of the first arrest have some bearing on parole success.'11

It can then be argued that a child offender could receive a double benefit, in that his youth is considered both at the sentencing phase and at the parole hearing. The age of a young offender, however, is not stated as a definite factor to be taken into consideration either in terms of the Parole Manual or in terms of legislation. The only indication that the young offender's age may be a factor is contained in the independent research undertaken by Louw and in Giardini's statement above. ${ }^{12}$ It is uncertain, however, whether the age factor in Louw's research is related to young age at the time of commission of the offence or to advanced age at the time of the parole hearing. (i.e. a life-sentenced offender who has reached the age of 65 may be placed on parole if he or she has already served 15 years of his or her sentence). ${ }^{13}$

It appears that the only concrete example of an age benefit coming into consideration at the parole hearing applies to the advanced age offenders mentioned above, as this is specifically provided for in legislation. ${ }^{14}$ Apart from that, adults, to whom that provision does not apply, and children are seemingly treated the same (despite the hypothetical argument canvassed above). The question can then be posed as to whether such a difference in treatment is desirable. This question will be answered with reference to international law provisions that influence the application of sentencing and parole, which are discussed below. In the meantime, it may be added that the 'discount' afforded to advanced age offenders makes little practical sense. The effect thereof is that someone who commits a life-sentence-worthy offence when he or she is 50 may only have to serve 15 years of a life sentence in prison. While, for example, a 17 -year-old may still have to serve 25 years before being considered for placement on parole (as this is the general non-parole period applicable to life-sentenced offenders). ${ }^{15}$ If one focuses on the age at the time of commission of the offence, it is questionable why a person

Director of Public Prosecutions, KZN v P 20061 All SA 446 (SCA) 451.

As referred to by GI Giardini The parole process (1959) 133 - 134.

Louw (n 1 above) 144.

Correctional Services Act 111 of $1998 \mathrm{sec}$ 73(6)(b)(iv).

As above.

As above. 
committing an offence at the age of 50 should benefit from special early release provisions while a 17-year-old offender should not.

\section{International provisions influencing sentencing and parole application}

At the outset, it may be noted that children in conflict with the law are dealt with by four main international instruments. ${ }^{16}$ These are the United Nations Convention on the Rights of the Child (CRC), ${ }^{17}$ the UN Guidelines for the Prevention of Juvenile Delinquency (Riyadh guidelines), ${ }^{18}$ the UN Standard Minimum Rules for the Administration of Juvenile Justice (Beijing Rules), ${ }^{19}$ and the UN Rules for the Protection of Juveniles Deprived of their Liberty (JDLs). ${ }^{20}$ Only the CRC is binding on South Africa as the South African parliament ratified it on 16 June 1995. None of the other instruments have been incorporated into our legislation. It should be noted, however, that law-making treaties might offer evidence of a widespread customary rule, in which case they could provide a basis for a legal obligation under customary international law that will be binding on nonsignatory states. 21

As already mentioned, the South African Bill of Rights provides, in section $28(1)(\mathrm{g})$, that every child has the right not to be detained except as a measure of last resort and only for the shortest appropriate period. In addition to that, section 28(2) significantly provides that a child's best interests be of paramount importance in every matter concerning the child. The standard of looking at what the child's best interest is has, in fact, often been described as a golden thread that runs through the whole fabric of the South African law relating to children. 22

The above provisions resonate clearly with international law provisions. For example, article 3 of the CRC also provides that the best interests of the child shall be a primary consideration in all actions concerning children. Article $37(\mathrm{~b})$ states that the arrest,

16 Brandt v S 2004 JOL 13262 (SCA) para 16.

17 United Nations Convention on the Rights of the Child, adopted by the UN General Assembly on 20 November 1989, Resolution 44/25.

18 United Nations Guidelines for the Prevention of Juvenile Delinquency, adopted by the UN General Assembly on 14 December 1990, Resolution 45/112.

19 United Nations Standard Minimum Rules for the Administration of Juvenile Justice, adopted by the UN General Assembly on 29 November 1985, Resolution 45/113.

20 United Nations Rules for the Protection of Juveniles Deprived of their Liberty, adopted by the UN General Assembly on 14 December 1990, Resolution 45/113. Also known as 'the JDL's'.

21 J Dugard International Law: A South African perspective (2005) 28.

22 B Bekink \& M Bekink 'Defining the standard of the best interest of the child' (2004) 1 De Jure 21. 
detention or imprisonment of a child shall be in conformity with the law and shall be used only as a measure of last resort and for the shortest appropriate period of time. Similarly, article 17(1)(b) of the Beijing Rules provides that restrictions on the personal liberty of the juvenile shall be imposed only after careful consideration and shall be limited to the possible minimum. Article 19(1) of the Rules adds that the placement of a juvenile in an institution shall always be a disposition of last resort and for the minimum necessary period.

It is perhaps important to point out the reason for the special protection of children and the reason why their best interests should form a primary consideration in the administration of juvenile justice. It has been stated that children differ from adults in their physical and psychological development as well as their emotional and educational needs. ${ }^{23}$ These differences, amongst others, constitute a basis for the lesser culpability (culpability here relates to blameworthiness, and thus involves the element of fault) of children in conflict with the law and justify a separate juvenile justice system and a different treatment for children. ${ }^{24}$ Preference should thus be given to aims such as rehabilitation and reintegration into the community. ${ }^{25}$ The Beijing Rules recognise this by providing, in article 2(2)(a), that a juvenile is a child or young person who, under the respective legal systems, may be dealt with regarding an offence in a manner that is different from an adult. Liefaard states that it is defensible to call for terms that are much shorter than those regarding adults at every stage. ${ }^{26}$

In returning to the discussion, it must be identified that international law provisions seem to go materially further than those of domestic law do. Article 3(3) of the Beijing Rules provides that efforts shall be made to extend the principles embodied in the Rules to young adult offenders. Furthermore, the commentary on article 17(1)(b) mentions that whereas in adult cases, and possibly also in cases of severe offences by juveniles, just desert and retributive sanctions might be considered to have some merit; in juvenile cases such considerations should always be outweighed by the interests of safeguarding the well being and future of the young person.

The above seems to tentatively imply that it is not only the best interests of the child that are worthy of protection, but that that child's future development as an adult is also of concern. It recognises that children under the age of 18 should not be viewed as existing in

23 UN Committee on the Rights of the Child (25 April 2007) General Comment 10: Children's rights in juvenile justicjustice, UN CRC (25 April 2007), UN Doc CRC/C/ GC/10para 10.

24 As above.

25 As above.

26 T Liefaard Deprivation of Liberty of Children in Light of International Human Rights Law and Standards (2008) 207. 
a vacuum. The serving of a sentence is a process, and particularly for children sentenced to life imprisonment, a particularly long one. Many children, who are sentenced for offences that they commit as children, remain in corrective facilities long past the age of adulthood.

In view of the above, it is my submission that the aims of childoffender-specific rehabilitation should not be abandoned upon the reaching of 18 years of age. It is the age at commission of the offence, which should be decisive upon continued treatment after reaching the age of 18. In other words, a child offender upon reaching the age of 18 should not suddenly be subject to the same rehabilitative programmes applying to adult offenders but, in view of their earlier separation from adult offenders and their consequently differing developmental needs, their age at the time of commission of the offence should continue to be taken into account. The commentary on article 19(1) of the Beijing Rules lends support to this argument. It states that:

Rule 19 aims at restricting institutionalisation in two regards: in quantity ('last resort') and in time ('minimum necessary period'). Rule 19 reflects one of the basic guiding principles of resolution 4 of the Sixth United Nations Congress: a juvenile offender should not be incarcerated unless there is no other appropriate response. The rule, therefore, makes the appeal that if a juvenile must be institutionalised, the loss of liberty should be restricted to the least possible degree, with special institutional arrangements for confinement and bearing in mind the differences in kinds of offenders, offences and institutions.

This argument can be supported by analogy with reference to another instance where an adult can benefit from provisions aimed specifically at children, that is, where a person who committed an offence as a child is only sentenced after he has turned 18. In this instance, Liefaard explains, ${ }^{27}$ (article 40 of the CRC provides that state parties recognise the right of every child alleged as, accused of, or recognised as having infringed the penal law to be treated in a manner consistent with the promotion of the child's sense of dignity and worth, which reinforces the child's respect for the human rights and fundamental freedoms of others and which takes into account the child's age and the desirability of promoting the child's reintegration and the child's assuming a constructive role in society) is still applicable to such offender in accordance with what he refers to as the 'crime date criterion' and that consequently he is also entitled to treatment in accordance with article 37 of the CRC (placement in a child facility). He states that this criterion 'is directly related to the ratio behind and legal foundation of a juvenile justice system, which aims at responding to the child's behaviour as a human being who is 
less culpable'. Clearly, reaching the age of 18 does not completely deprive persons who committed offences as children from benefiting (in some way) from the applicability of provisions aimed at such children in particular. Alternatively, it can be stated that, for a child offender who turns 18 while still under the control of corrections, some benefits relating to his age at the time of commission of offence, remain intact.

Coming back to the criterion of institutionalisation for the minimum amount of time, article 28(1) of the Beijing Rules must also be mentioned. It states that conditional release shall be used to the greatest possible extent and shall be granted at the earliest possible time. This can be read together with the further comment under article 19, which states that:

Progressive criminology advocates the use of non-institutional over institutional treatment. Little or no difference has been found in terms of the success of institutionalisation as compared to noninstitutionalisation. The many adverse influences on an individual that seem unavoidable within any institutional setting evidently cannot be outbalanced by treatment efforts. This is especially the case for juveniles, who are vulnerable to negative influences. Moreover, the negative effects, not only of loss of liberty but also of separation from the usual social environment, are certainly more acute for juveniles than for adults because of their early stage of development.

In view of the above, it makes sense that early release of child offenders is desirable. If one considers that young offenders who reach the age of 18 are soon thereafter transferred to an adult facility, and (it can be argued) exposed to increased negative influences, an argument for early conditional release gains further weight, if the rehabilitation and reintegration of child offenders into society is kept in mind. The fact that the UN has identified the prevention of juvenile delinquency as one of the most important aims of the implementation of the CRC and a core element of a comprehensive juvenile justice policy of any states party ${ }^{28}$ makes the argument even stronger. The CRC requires states to develop and implement such a comprehensive juvenile justice policy, which is to encompass all relevant articles of the CRC. ${ }^{29}$

It is noteworthy that the Committee on the Rights of the Child has gone even further and recommended that all forms of life imprisonment for offences committed by persons under the age of 18 should be abolished. This is because the likelihood that life imprisonment of a child will make it very difficult, if not impossible, to achieve the aims of juvenile justice despite the possibility of release. ${ }^{30}$ Article 79 of the JDLs provides further that all juveniles 
should benefit from arrangements designed to assist them in returning to society, family life, education, or employment after release. Procedures, including early release, and special courses should be devised to this end.

\section{Conclusion}

Having considered the provisions of international law instruments relating to the imprisonment and parole of child offenders, in addition to the relevant principles contained in South African law, one can easily come to the conclusion that South Africa treats child offenders (as far as parole is concerned) in a less favourable manner than is desirable.

The deprivation of liberty as a measure of last resort and for the shortest period of time means that state parties should have a welltrained functionary in place which can make maximum and effective use of measures such as, inter alia, the possibility of early release from detention. ${ }^{31}$ Furthermore, in cases of severe offences by children, the need to safeguard the well-being and the best interests of the child and to promote his reintegration must always outweigh the need for public safety and sanctions. ${ }^{32}$ This reintegration aim is also envisaged by article 40 of the CRC. In fact, the Committee on the Rights of the child has recognised that the aim of preservation of public safety is best served by a full respect for and implementation of the overarching principles of juvenile justice as enshrined in the CRC. 33

South Africa, it has been noted, possesses a lack of qualified professional personnel available to aid child (and other) offenders with their rehabilitation and reintegration back into society. It has also been established that children have special developmental needs, and that certain benefits to children should not and do not automatically cease upon the reaching of 18 years of age. This and the fact that children who reach 18 years of age are soon thereafter transferred to adult facilities, presenting them with tangibly worse influences, favours decreased incarceration for such offenders in the form of accelerated parole consideration. The crime date criterion should guide such accelerated consideration.

Related to the above is the argument that children and adults should be treated differently when it comes to parole. Article 2(2)(a) of the Beijing Rules states that children may be dealt with for an 
offence in a manner different from adults. This further supports an argument for accelerated parole consideration for child offenders.

One should keep in mind that additional benefits to child offenders are not to be seen as characteristic of a juvenile justice system which 'slacks off' in the punishment of child offenders, but rather as belonging to a system which takes the aims of protection of the society as well as of rehabilitation and reintegration of such children seriously. 



\section{AMBUSH MARKETING: THE KULULA.COM PERSPECTIVE}

by $R$ Kgobokoe*

\section{Overview}

Ambush Marketing is often described as a type of 'parasitic marketing.' However, before we look into ambush marketing one has to consider the essence of marketing and more specifically, advertising. The purpose of advertising is essentially to create brand awareness, by somehow making the public aware of the product you offer as a company or firm. Sponsorship is a mechanism through which brand awareness can be created. Sponsorship can be defined as a commercial arrangement, whereby a sponsor pays a certain sum of money (a sponsorship fee) or provides certain products, services or other facilities to the sponsored party, in return for which, the sponsor is granted certain rights of association with the sponsored party. ${ }^{1}$ What better way to create awareness than at a major global event? By paying the event organisers an agreed amount, they associate your product with their event. For instance, First National Bank (FNB) agree to sell the Fédération Internationale de Football Association (FIFA) world cup tickets at their branches across the country without sharing in any of the profits, they may not be generating any money from actual ticket sales but they get thousands of people coming in and out of their branches daily, thus more importantly, creating band awareness. ${ }^{2}$ Sponsors should be protected by organisers from unofficial non-sponsors, but to what extent? While the law should attempt to safeguard the investments of sponsors of events, we should not be unreasonable in our attempts. Laws and regulations should be applied with at least a modicum of sanity and those responsible for their enforcement should avoid adopting a dictatorial approach.

\section{Ambush Marketing}

The Advertising Standards Authority (ASA) in its sponsorship code defines ambush marketing as:

Reba Kgobokoe, final year LLB student, University of Pretoria.

S Gardiner Sports Law 2nd Ed (2001) 507.

This hypothetical scenario might not be too far fetched. 
The attempt of an organisation, product or brand to create the impression of being an official sponsor of an event or activity by affiliating itself with that event or activity without having paid the sponsorship rights-fee or being a party to the sponsorship contract. ${ }^{3}$

In layman's terms this simply means that ambush marketing occurs when an organisation claims association to an event on which it did not, legally, spend a cent to claim such association.

In broad terms, ambush marketing is said to take two forms, namely: Association and Intrusion.

\subsection{Association}

The ambush marketer misleads the public into thinking that he is an authorised sponsor or contributor associated with an event. ${ }^{4}$ 'Association' occurs through the use of the insignia of the event or insignia which are similar to such insignia which may cause confusion, or by misrepresenting that the marketer or his product is associated with the event.

\subsection{Intrusion}

The ambush marketer does not seek to suggest a connection with the event but rather to give his own brand or other insignia exposure through the medium of the publicity attracted by the same event without the authorisation of the event organiser. ${ }^{5}$ Ambush marketing by intrusion will include the following examples:

(a) A marketer who markets his product or brand by creating a promotional competition in which he makes reference to an event which has been sponsored.

(b) The advertising of a brand or product outside or in close vicinity to a stadium where an event which is sponsored is taking place.

(c) The flying of an airplane or blimp with advertising on it over a stadium at which a sponsored sporting event is being held.

In both association and intrusion the aim is to use a sponsored event to market a product or brand without bearing the financial costs.

There are also various categories of ambush marketing within this broad framework, including: 6

http: / /www.asasa.org.za (accessed 5 May 2010).

O Dean 'Ambush marketing' (2000) June De Rebus 24.

Dean (n 4 above) 24.

There are various other forms of ambush marketing however the focus of this discussion is advertising. 


\subsubsection{Unauthorised use of intellectual property rights}

An example of this could be 'Passing-off'. Passing off occurs when a competitor uses the trademarks of his opponent in order to create the impression that his performance is similar to or associated to the already well-known performance of his opponent thus deceiving and influencing consumers to accept his performance. ${ }^{7}$

\subsubsection{Broadcast sponsorship}

This could simply be done by broadcasting an event without the rights.

\subsubsection{Advertising}

For example, the bulk purchase of advertising in selected media in and around an event by an unofficial supplier seeking to take advantage of the name and reputation of the event is relatively straight forward: such advertising need not make specific reference to the event, but just to the particular sport or activity involved. In a recent advertisement, Kulula.com advertised itself as the 'unofficial carrier during the: you know what!' Kulula.com did not make any specific reference to the world cup, but an association was obvious ... during the period of the 'YOU KNOW WHAT'. Such reference is unlikely to infringe any intellectual property right but can definitely result in a high identification on the part of the public with the event in question.

The 2002 World Cup in football was beset with ambush marketing incidents. FIFA ${ }^{8}$ is reliant on revenue from exclusive sponsorships. Coca Cola was one of the sponsors of the World Cup. A television commercial by its non-sponsoring competition, PepsiCo, featured leading footballers playing against a world cup backdrop featuring a cohort of sumo wrestlers. With the World Cup having come to South Africa in 2010, FIFA took the opportunity to set an example and thus set a precedent against any would be ambush marketers. An application was brought to the High Court, in which interdicts against Eastwood Tavern were sought. These interdicts were sought on the basis of:

(i) Infringing a registered trademark namely 'World Cup 2010,' 'South Africa 2010' and 'Twenty Ten South Africa';

(ii) Passing off under the common law;

HB Klopper \& P Van der Spuy Law of Intellectual Property (2008) 106. Federation International de Football Association. 
(iii) The violation of section 15A of the Merchandise Marks Amendment Act ${ }^{9}$ and section 9(d) of the Trade Practices Amendment Act. ${ }^{10}$

Eastwood Tavern is a restaurant located in the vicinity of one of the 2010 Soccer World Cup Stadiums being Loftus in Pretoria. The restaurant's front signature had the words 'World Cup 2010' emblazoned on it along with the flags of a number of participating countries.

The South African parliament amended its trade practices legislation to respond to the anticipated problem of ambush marketing. The new law prohibits commercial statements that suggest or imply a contractual or other connection with a sponsored sports event or a person sponsoring an event. Parliament also amended merchandise marks legislation specifically to prohibit infringement of intellectual property rights in connection with (before, during and after) officially protected events. Sanctions for violation of either law include stiff fines and imprisonment of offenders.

These legislations were applied successfully in the case of FIFA v Metcash Trading Africa (Pty) Ltd. ${ }^{11}$ Metcash produced a lollipop product which was marketed as '2010 Pops' and featured images of soccer balls similar in design to the official ball used by FIFA in a past tournament, together with the South African flag. The court found in favour of FIFA, finding that Metcash intended its lollipop product to be associated with the 2010 FIFA World Cup and to derive a special promotional benefit from the event.

\section{Ambush Marketing and the Constitution (The Kulula.com perspective)}

Ambush marketing is not ordinarily illegal insofar as it does not involve trademark piracy. The Kulula.com advertisement has carefully avoided any trademark violation. They clearly state that they are 'unofficial', they do not make any blatant affiliation with FIFA, instead they seem to be looking to be operative like any business would during the world cup. Ambush marketing legislation can not certainly be looking to stifle the growth of non-associated organisations during major events. If one was to consider Section 16 of the Constitution, ${ }^{12}$ in $16(1)$ it clearly states that everyone has the right to freedom of expression, which includes: (a) freedom of the press and other media; (b) freedom to receive or impart information

11 FIFA v Metcash Trading Africa (Pty) Ltd (2009) JOL 24382 (GNP).

12 The Constitution of the Republic of South Africa, 1996. 
or ideas; (c) freedom of artistic creativity; and (d) academic freedom and freedom of scientific research.

It should always be borne in mind that these rights are guaranteed by the Constitution, even though some of the limitations of ambush marketing may be justified in terms of the section 36 limitation clause in the Constitution, it is important that we should avoid getting carried away by the whole ambush marketing phenomenon. The whole country should not come to a halt all in the name of the World Cup. Sponsoring organisations should have their sponsorships protected but surely strong competition should still be allowed to exist. It is important not to allow organisations such as FIFA to intimidate local business and stifle free trade. If the highest bidding sponsor is guaranteed exclusive protection at the expense of smaller non-associated organisations then are not we stunting growth and building monopolies. In an economy which notoriously favours the rich, should we not rather see the FIFA world cup as an opportunity to spread the wealth instead of allowing FIFA and big business to continue its parasitic dominance? The official beer of the World Cup was Budweiser, this was the case in Germany 2006, and they also have the rights to the next event in 2014. Budweiser is not even a South African beer. What is the point of even having a World Cup in South Africa? Granted many jobs were created during the intense construction in and around the major cities, but what about the loss in sales for companies like SAB miller? There are even marketing exclusion zones surrounding stadia, the 2010 FIFA World Cup South Africa Special Measures Act, 2006 has made specific provision for the establishment of such areas. This will ensure that the bigger organisations become immortal while the smaller ones eventually disappear. This is surely an opportunity for the Competition Commission to intervene.

There seems to be a trend in many jurisdictions to address the problem of ambush marketing by means of specialised legislation. This is driven by the realisation that ambush marketing is causing harm, not only to legitimate sponsors of events but also to sports bodies as well as the economies of regions or countries. FIFA works all year and all around the world to ensure that its official trademarks and other intellectual property rights are properly protected and enforced. The Rights Protection Programme is aimed primarily at tackling organised ambush marketers, counterfeiters and unauthorised traders, all of whom seek to profit from an event to which they have not contributed. In South Africa the Official Marks are protected by the Trade Marks Act, ${ }^{13}$ the Copyright Act, ${ }^{14}$ the Counterfeit Goods Act, the common law delict of passing off in 
addition to other specific statutory provisions such as the Trade Practices Act and the Merchandise Marks Act. It is fair to combat nonofficial sponsors, but prohibitions should not be aimed at entrenching monopolies. FIFA has made government divert development money into fancy stadiums, and at the same time local business had to give up all sorts of rights during the world cup. Taking that into consideration, ambush marketing regulation should be done with a little common sense. Companies such as Kulula.com, should still be able to advertise their competitive prices to the huge foreign contingent that was in South Africa during the event, measures should obviously be put in place to control any form of 'parasitic advertising' but at the end of the day, the World Cup coming to South Africa is meant to have far reaching benefits for everyone. These are the sort of ideals our Constitution was founded upon: 'Better life for ALL!'15 


\title{
THE GREAT MOVE TOWARDS OPENNESS IN ADOPTION
}

\author{
by N Da Rocha*
}

\section{Introduction}

Many noteworthy changes have occurred in South African adoption law in the recent past: With the enactment of the Children's Act, ${ }^{1}$ various new concepts have been provided for. A post-adoption agreement is one such concept. ${ }^{2}$ This provision allows the Children's Court to grant an order confirming an agreement whereby the biological parent/s or guardian/s of a child would have the benefit of either communication or contact with the adopted child, or the right to be provided with certain information concerning such child.

An application for judicial approval of a post-adoption agreement is brought before the court simultaneously alongside the adoption order. This is a major step towards the concept widely known in the international community as 'openness' in the adoption process, and away from the secrecy which dominated adoptions in the past.

Currently in South Africa, adoption may be described as an '.. order [which] has the effect of creating a legal relationship between the adoptive parent and the adopted child in the interests of the child. ${ }^{3}$ This involves the severing of legal ties between the birth parents and their child, relinquishing all parental rights and responsibilities and handing them over to the adoptive parents. Therefore in the eyes of the law, the adopted child is, for all purposes, the child of the adoptive parent/s.

Due to the fact that this is the first time the South African legislature has sought to provide for and regulate post-adoption contact, this article serves as an exploration into the new possibilities and struggles South Africa may face in this regard.

\section{The adoption spectrum}

As explained by the American governmental department of Child

Nicole Da Rocha, fourth year LLB student, University of Pretoria.

Act 38 of 2005 ('the Act').

Provided for in s 234 of the Act.

A Louw 'Adoption of children' in T Boezaart (ed) Child law in South Africa (2009) 133. 
Welfare, open adoption is the opportunity granted to adoption parties whereby they '... allow adoptive parents, and often the adopted child, to interact directly with birth parents. ${ }^{4}$ In a publication by the same department five years later, this definition was extended to include not only birth parents but also '... other persons with whom the child has an established relationship ...'.5

Interaction or contact can take place in various forms and to various degrees. We can therefore view adoption as a spectrum of diverse options. On the one end of the adoption spectrum we have completely confidential (closed) adoptions, while to the opposite end of the spectrum we have what we may refer to as fully disclosed (open) adoptions. ${ }^{6}$ In the middle of this scale are mediated (semiopen) adoptions.

The degree to which an adoption will be open depends completely on the parties to the adoption. The various degrees of openness enable '... family members to interact in ways that feel most comfortable to them.'

Before an adoption order is made, merely allowing the adoptive parent to be involved in the selection process for adoptive parents without any further contact with them or the child given up for adoption thereafter, is considered a form of open adoption practice. ${ }^{7}$ The biological parent is given particular identifying information about the prospective adoptive parents in order to make the decision. ${ }^{8}$ Similarly, prospective adoptive parents who receive medical information (particularly medical history) from a birth parent prior to an adoption, generally with the aim of wanting to be fully informed with regard to a child they may adopt, also exercise a form of open adoption practice. ${ }^{9}$

Mediated (semi-open) adoptions occur where parties consent to the exchange of information relating to the adoptee but do not wish to have direct contact occur between the birth parent/s and the adoptee. The information is then relayed to the particular party via a mediator (such as an attorney or social worker). ${ }^{10}$ The parties in this case may agree to what type of information is exchanged.

4 http://www.childwelfare.gov/pubs/f_openadoptbulletin.cfm (accessed 6 July 2010).

5 www.childwelfare.gov/systemwide/laws_policies/statutes/cooperative.cfm (accessed 6 July 2010).

6 As above.

7 L Gaddie 'Open adoption' (2009) 22 Journal of the American Academy of Matrimonial Lawyers 499.

8 www.childsafety.qld.gov.au/legislation/documents/consult-chap04.pdf (accessed 1 August 2010).

9 http://adc.bmj.com/content/95/1/7.extract (accessed 1 August 2010).

10 n 5 above. 
The exchange of information may be regulated by an agreement such as the one envisaged in section 234(1)(b) of the Act, and therefore can continue to take place long after the adoption order is granted. Since this section does not specify whether such an exchange should take place via a mediator or directly between the parties, this is a point which should be agreed upon by the parties themselves.

Post-adoption communication between the adoptive family and birth relatives may occur in a number of ways - they may agree to the exchange of letters, e-mails and telephone calls, or consent to the granting of visitation rights. ${ }^{11}$ The parties also agree to how frequent communication may take place. This is what the legislature has provided for in section 234(1)(a) of the Children's Act.

When parties are in the process of negotiating the parameters of an adoption order, they must take into consideration the needs and wishes of all parties involved. Paramount to all this however is the best interests ${ }^{12}$ of the adoptee, a standard entrenched by the South African Constitution.

A post-adoption contract therefore, is concluded by the parties to an adoption for the purpose of specifying the type and frequency of contact after the adoption order is granted..$^{13}$ One must not make the error in thinking that open adoption creates a 'shared care' or joint care arrangement between adoptive parents and birth parents ${ }^{14}$ - since an adoption, no matter how open it is, still results in the total relinquishment of the birth parents' parental rights and responsibilities. ${ }^{15}$

\section{Why encourage open adoption practice?}

The ultimate purpose for concluding a post-adoption agreement is to contribute to the success of the adoption ${ }^{16}$ by recognising what is best for the wellbeing of the child and simultaneously making an effort to cater for the other parties' interests as far as reasonably possible. Open adoption therefore, does not describe a single practice or refer to only one part of the adoption process.

The government of Queensland, a state of Australia, conducted an extensive investigation beginning in 2002 in an effort to ascertain the best adoption practices in Australia and from around the world. The

1 n 5 above.

$12 \mathrm{Sec} 28$ of the Constitution of the Republic of South Africa, 1996 ('the Constitution').

n 5 above.

n 7 above, 499.

n 3 above, 133.

www.childsafety.qld.gov.au/legislation/documents/future-adoption-laws.pdf (accessed 3 September 2010). 
investigation concluded with numerous reasons for legislating in favour of open adoptions. ${ }^{17}$

Firstly, open adoption practice takes cognisance of the fact that adoption does not result in the removal of the existence of children's birth parents from their lives. Rather, it recognises that adoptees have birth parents as well as adoptive parents. Open adoption practices may consequently be utilised as a mechanism to ensure that the interests of both sets of parents attain equal respect in the adoption process.

The investigation also highlighted the fact that adoption results in children having one set of legal parents, namely their adoptive parents. It is an important fact to remember:

Adoption results in the severance of legal ties between the adoptee and birth parent, the fact that an adoption is open and subject to a postadoption agreement does not create a joint care arrangement between adoptive parents and birth parents.

An exceptionally important revelation surfacing from the investigation is that children benefit from knowing about their birth parents and the circumstances of their adoption. This fact will undoubtedly lend to the increase in utilisation of open adoption practices since the welfare of the child is the paramount concern.

Much research has been conducted in order to ascertain the effects of open adoptions on the parties to the adoption arrangement. Research shows that many fears regarding open adoption are merely based on myths. The results obtained by the American Child Welfare governmental department in this respect will now be briefly discussed. ${ }^{18}$

It has been found that parties in fully disclosed adoptions are not confused about their parenting rights and responsibilities and therefore adoptive parents in open adoptions do not feel less in control but rather have a healthy sense of permanence in their relationship with their child. Likewise, the adoptee is not confused about who his or her parents are - research shows that children understand the different roles of adoptive and birth parents in their lives.

The research also states that 'open adoption does not interfere with adoptive parents' sense of entitlement or sense that they have the right to parent their adopted child ...' and contrary to widely held assumptions, birth mothers do not attempt to 'reclaim' their children. 
American child welfare experts profess that full disclosure does not appear to influence an adoptee's self-esteem in any negative way and '... birth mothers in open or ongoing mediated adoptions do not have more problems with grief resolution; indeed, they show better grief resolution than those in closed adoptions. ${ }^{19}$

With the welcoming of open adoption practices in South Africa comes a range of flexible options available to persons involved in an adoption. It enables parties to agree on an adoption plan which they may specifically tailor to meet the needs and wishes of all relevant people as far as possible.

By disclosing medical information for example, it allows the adoptive parents to make an informed choice as to the child they will be parenting; enabling them (and the adoptee) to be somewhat prepared for any current or future health risks the child may carry. ${ }^{20}$ The fact that family history is a central enquiry in any paediatric consultation reminds us of the importance of full medical disclosure.

From the adoptee's perspective, a lack of knowledge about her birth family's medical history leaves a significant gap in her future understanding of her own personal health risks. ${ }^{21}$ Therefore it seems it would be quite beneficial for the persons involved that it should become standard practice to encourage at the very least, full disclosure of medical information by the birth family.

The Constitution sets the best interests of the child as the paramount consideration, ${ }^{22}$ section 234 of the Act provides a great step toward achieving the best interests of a child as it is now possible through a post-adoption contract to

... [M]inimise the child's loss of relationships ... [as well as] maintain and celebrate the adopted child's connections with all the important people in his or her own life, and ... allow children to resolve losses with truth, rather than fantasy. 23

Adoption enables children to grow up in a family setting which in Louw's opinion '... provides a child with a constitutionally entrenched form of care and protection that is unsurpassed by any other form of permanent placement in securing stability in child's life. ${ }^{24}$ Louw has previously expressed the hope of how '[t]he possibility of ensuring contact with a child after adoption may significantly improve the

There are countless dedicated websites and members of society however, that believe what is purported in publications, such as the results released by American Child Welfare, amount to mere propaganda in order to increase the utilisation of adoption.

20 n 9 above.

21 n 9 above.

22 Entrenched in s 28 of the Constitution.

23 n 7 above, 499.

24 A Louw 'Adoption of children' in Boezaart (n 3 above) 133. 
chances of a parent making a child available for adoption. ${ }^{25}$ One would thus think another important advantage South Africa will see in the introduction of open adoption practices is that it will contribute to an increase in the use of adoption as an alternative placement for children in need of care and protection.

An interview was conducted with Jeanie Lucas, ${ }^{26}$ who is the senior project officer of adoption, family records and post care in the government department for families and communities of South Australia. When put to her whether post-adoption contracts ${ }^{27}$ have encouraged the use of adoption and as a result caused an increase in the number of adoptions concluded in Australia, she made the following remark:

We have no research on this in our State, but it would seem that it has had no or negligible effect. A post adoption arrangement is seen as a normalised part of the adoption process in the child's best interest and is not seen as a 'sweetener' or an added extra.

The issue of grief and loss as addressed in the counselling process with the child's birth parents is a significant part of the work; the post adoption arrangement is approached as a part of the process and birth parents are presented with the idea that a post adoption arrangement carries its own challenges and is not a mechanism to alleviate grief and loss, and indeed could present challenges that add to it.

Fehlberg, ${ }^{28}$ a respected professor at Melbourne Law School, agrees that although the majority of adoptions taking place are now open, this has made no difference to the number of adoptions concluded in Australia. She stated further that birth mothers actually tend to withdraw from the adoption family over time. ${ }^{29}$ Carney, professor of law at the University of Sydney, pointed out that overall, open adoption has been very successful in the advancement of the human right to identity, in that the child is able to grow up informed about his or her biological background and any other information the parties wish to convey, such as the circumstances which led to the adoption. 30

It would seem therefore that Louw's hopes that the introduction of open adoption practices will see an increase in adoptions within South Africa may not come to fruition. In Australia where the utilisation of adoptions has been remarkably low, statistics released

A Louw 'Adoption of children' in Boezaart (n 3 above) 150.

E-mail from J Lucas on 26 August 2010.

Or 'adoption plans' as it is commonly known in Australia.

E-mail from B Fehlberg on 26 August 2010.

The withdrawal may take place for a range of reasons, such as the fact that since a post-adoption agreement is not enforceable, the birth parent is totally reliant upon the good will of the adoptive parents. For many birth parents, restricted contact to the child can be very painful and emotionally challenging.

30

Email from T Carney on 25 August 2010. 
as current as February $2010^{31}$ seem to support Ms Lucas's submission. ${ }^{32}$ Then again, adoption in Australia as previously pointed out, has had a tortured and painful history. It remains to be seen then, whether the introduction of open adoption practices by way of section 234 of the Children's Act shall have any effect on the increase in utilisation of the adoption process.

While no averment can be made that all problems faced in adoption will be solved under an open adoption plan, it is clear that open adoption addresses some very basic dilemmas and offers a psychologically healthier way in handling the needs of the individuals involved.

\section{The disadvantages of open adoption practices}

One of the major disadvantages encountered occurs as a result of the lack of provision of formal procedures and judicial enforceability with regards to post-adoption contracts. In numerous countries no remedy is available in cases where a party to an open adoption plan fails to comply with the terms agreed to. The lack of enforceability thus allows any party to freely depart from the terms of a post-adoption agreement, without suffering any legal consequences.

It is for this reason that section 167(1)(a) of the Adoption Act 2009 of Queensland, for example, proves problematic. In terms thereof, parties may very well consent to an adoption plan in conjunction with the adoption order; however the same provision does not give the adoption plan any legal force. Without judicial enforcement, how are parties to ensure that the plan is indeed complied with? At best, the parties may have agreed in the contract to refer any dispute to an alternative dispute resolution practice.

Logically, this is problematic to those birth parents who gave their child up for adoption with the promise of post-adoption contact. ${ }^{33}$ The lack of judicial enforceability of such agreements may certainly encourage coercion of birth parents' in relinquishing their parental rights and responsibilities with no intention on the part of the adoptive parents of ever fulfilling the terms set out in the informal contract. 34

Section 234(6)(a) of the Children's Act expressly states however, that a post-adoption agreement shall have affect once it is made an

31 The statistics evidence that since the late 1990s the numbers of adoption have fluctuated from year to year, but remained relatively stable at around 400 to 600 children per year.

32 Higgins 'Impact of past adoption practices: Summary of key issues from Australian research' (2010) Melbourne: Australian Institute of Family Studies 2.

33 n 7 above, 500.

34 As above. 
order of court. As a formal order of court the parties involved are protected should any person to the agreement not comply with the terms they have agreed to. The Act also enables the contract to be amended or terminated solely by an order of court should either of the parties later feel it is in the child's best interests to do so.

Another major struggle, which has arisen following the advocating of open adoption practice, concerns the exchange of information. In the UK for example, contemporary adoption practice encourages candid disclosure of medical information to adoptive parents. However, medical professionals have pointed out the struggles they face in situations where adoptive parents wish to have access to information regarding the birth parents in order to ascertain the child's medical history; but the birth parents do not wish to disclose any information at all. 35

In cases such as these, one is faced with the difficulty of balancing the right a birth parent has to confidentiality, with the need of the adoptive parent to be fully informed with regards to the child he or she will have to parent. One could even argue that the exchange of information would be in the best interests of the child since the adoptee benefits from being parented by a person who understands the child's needs and is aware of the adoptee's medical history. Therefore the right to confidentiality competes with the rights of the child too.

As open adoption practice becomes increasingly utilised in South Africa, our welfare workers may face the same difficulties in practice. The judiciary will no doubt sooner or later be required to make decisions concerning the challenges of balancing the constitutionally entrenched right to privacy, ${ }^{36}$ with the interests of the adoptive parents and adopted child to be informed-keeping in mind that our Constitution requires that the best interests of the child be paramount at all times. ${ }^{37}$

In 2003 a UK High Court judged that a local authority adoption agency fell below the reasonable standard of care when it failed to provide sufficient information about a child's potential behavioural difficulties to adoptive parents. ${ }^{38}$ This case highlights the difficulty for social workers in determining where to draw the line with regard to protecting the confidentiality of the birth family. Perhaps this court's ruling lends a solution for our courts in future, ${ }^{39}$ since such a

n 9 above.

Sec 14 of the Constitution.

$\mathrm{Sec} 28(2)$ of the Constitution.

n 9 above.

'When the courts are required to interpret any right under the Bill of Rights, it must consider foreign law' - sec 39(c) of the Constitution. 
ruling surely favours the best interests of the child and thus reiterates the best interests rule in section 28 of the Constitution.

Another matter of dispute was settled by the UK court of appeal: The court had to deal with the delicate question as to how far the court can or should go in imposing on adoptive parents obligations which they may be reluctant to assume voluntarily. ${ }^{40}$ The court of appeal stated unequivocally in its judgement that since the birth parents parental rights and responsibilities were extinguished by the operation of law when the adoption was concluded, it is the adoptive parents who make the decisions as to what they deem to be in the child's best interests, since for all purposes, they are the child's legal parents. The court further held that the defence relied upon by the birth parent - that they had a right to family life; does not apply once an adoption order is granted. ${ }^{41}$ The court therefore found that it is extremely unusual to place upon the adoptive parents obligations which they are unwilling to assume - the court therefore found in favour of the adoptive parents.

\section{A critical analysis of section 234 of the Children's ${ }^{42}$ Act}

The exact wording of the section reads as follows:

(1) The parent or guardian of a child may, before an application for the adoption of a child is made in terms of section 239 , enter into a post-adoption agreement with a prospective adoptive parent of that child to provide for:

(a) communication, including visitation between the child and the parent or guardian concerned and such other person as may be stipulated in the agreement; and

(b) The provision of information, including medical information, about the child, after the application for adoption is granted.

(2) An agreement contemplated in subsection (1) may not be entered into without the consent of the child if the child is of an age, maturity and stage of development to understand the implications of such an agreement.

(3) The adoption social worker facilitating the adoption of the child must assist the parties in preparing a post-adoption agreement and counsel them on the implications of such an agreement.

Oxfordshire County Council $v X$ and others [2010] 2 FCR 355.

[2010] 2 FCR 355 at 368.

Hereinafter referred to as 'the Act'. 
(4) A court may, when granting an application in terms of section 239 for the adoption of the child, confirm a post-adoption agreement if it is in the best interests of the child.

(5) A post-adoption agreement must be in the prescribed format.

(6) A post-adoption agreement:

(a) takes effect only if made an order of court;

(b) may be amended or terminated only by an order of court on application:

(i) by a party to the agreement; or

(ii) by the adopted child.

The above legislation therefore only permits parties to conclude a post-adoption agreement at a specific time, that being before an adoption order is granted in terms of section 239 of the same Act. By operation of law, once an adoption order is granted all parental rights and responsibilities belonging to the birth parents are extinguished and are vested in the adoptive parents.

As pointed out in a UK court of appeal: It is rather unusual to impose obligations upon the adoptive parents once an adoption order has been granted; particularly obligations which they are reluctant to voluntarily assume. ${ }^{43}$ It is therefore not irrational to expect the parties to come to a decision as to whether they would like to conclude a post-adoption agreement before the adoption is granted, as you cannot expect adoptive parents to consent to undertake duties once they have attained full parental rights and responsibilities of the child concerned.

Before the inclusion of section 234 of the Act, academics questioned whether post-adoption agreements would be precluded from parties to informal adoptions. ${ }^{44}$ An informal adoption refers to those arrangements commonly made within black communities. The practice entails an informal arrangement to the effect that the child is 'adopted' by relatives or non-relatives, while maintaining links with the biological family, the child is then eventually returned to the biological family in his or her late teens or early adulthood.

Despite the fact that an adoption is only possible in terms of a statutorily prescribed court order, ${ }^{45}$ South African courts have in certain instances also given recognition to informal adoptions concluded within indigenous communities. ${ }^{46}$ Kewana $v$ Santam Insurance Co Ltd ${ }^{47}$ as well as Metiso v Padongeluksfonds ${ }^{48}$ are two

Gagne v Canada (Correctional Service) 20102 FCR 355.

A Louw 'Open adoptions: Panacea or Pandora's Box?' (2003) De Jure 274.

As prescribed in sec 239 of the Children's Act.

Due to the fact that adoption is still an alien concept in some of these communities.

$47 \quad 19934$ SA 771 (TKA).

$48 \quad 20013$ SA $1142(\mathrm{~T})$. 
such cases: The courts held that '... the child concerned was validly adopted in terms of customary law and was therefore entitled to compensation for the loss of support resulting from the negligent killing of the child's adoptive parent, as would be the position if a formal adoption had been concluded. 49

However, since section 234(1) of the Act makes specific reference to formal adoptions concluded in terms of section 239 of the Act only, it is clear the statute does in fact preclude parties to informal adoption arrangements made in terms of customary law.

A rather unfortunate limitation however is placed upon prospective parties to a post-adoption agreement, in that section 234(1)(a) and (b) of the Act has the effect that such agreement must provide for communication and the provision of information. Bearing in mind the general rules regarding the interpretation of statutes, every word must be considered by it is ordinary meaning and it cannot be assumed that the legislature used words carelessly or frivolously.

It therefore seems that where parties wish to conclude such an agreement in terms of section 234 of the Act, they are obliged to make provision for both communication and information with regard to the child, as the legislation does not provide for it in the alternative. Should parties to the agreement wish to make provision for the exchange of information regarding the child to the exclusion of any terms providing for communication, ${ }^{50}$ such agreement shall not be enforceable, as they would be unable to make it an order of court in terms of section $234(6)$ of the Act.

\section{Conclusion}

Open adoption is certainly a most welcomed concept for adoptions in modern society. The post-adoption agreement specifically, should prove to be a great step forward in the quest to better suit the needs of each individual child as required on a case by case basis. While the South African provision still has its limitations, the flexibility now afforded to parties to an adoption will certainly assist the court in granting an order which is tailor made for the needs and best interests of the adopted child.

Section 234 of the Act should prove to be a great advantage for older children going through an adoption process, as it allows the child to maintain significant relationships already in existence prior to the adoption order. Whether this provision will be greatly utilised by parties, to which a baby is the subject of the adoption, remains to be seen. 
It is vital to keep in mind that post-adoption agreements should not be used to coerce a birth parent to make his or her child adoptable, but rather it should be used as a tool in the adoption process which is available to the parties to allow them to reach a plan which is in the best interests of that child. Our courts must be careful to remain mindful of this. An open adoption approach presents its own challenges and therefore should not be agreed to lightly. 


\title{
THE STATE OF TEMPORARY EMPLOYMENT SERVICES IN DEMOCRATIC SOUTH AFRICA
}

\author{
by $T$ Nkabinde*
}

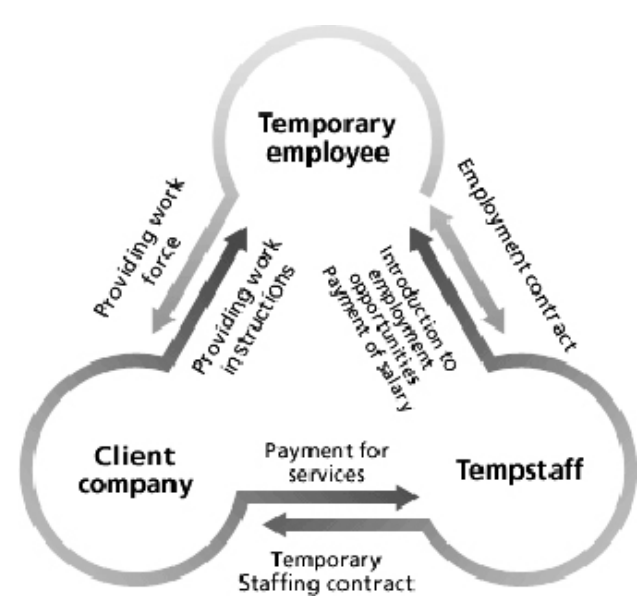

\section{Introduction ${ }^{1}$}

For many years now, South Africa, like many countries has legally recognised labour hiring as a form of employment, through various pieces of legislature. ${ }^{2}$ According to section $198(2)^{3}$ of the Labour Relations $\mathrm{Act}^{4}$ the parties in this tripartite relationship are the temporary employment service is known as the employer, the employee, who is the person who's been contractually procured for his services, and the client, who is the user enterprise that seeks the services of the temporary employment service. This type of employment has been under public and legal scrutiny for a while now

* Thandi Nkabinde, third year LLB student, University of Pretoria.

Image from: www.tempstaff.co.jp/personal/temporary.html (accessed 5 July 2010).

2 See Labour Relations Act 66 of 1995; Employment Equity Act 55 of 1998.

3 Sec 198(2): For the purposes of this Act, a person whose services have been procured for or provided to a client by a temporary employment service is the employee of that temporary employment service, and the temporary employment service is that person's employer.

4 Act 66 of 1995. 
because of malpractice(s) against employees. Trade Unions ${ }^{5}$ have called for the total banning of the operation of temporary employment agencies whereas some organisations ${ }^{6}$ including the Confederation of Associations in the Private Employment Sector (CAPES) have called for codes of conduct that will regulate the industry. The motor industry has recently banned ${ }^{7}$ the operation of temporary employment services in its sector, due to the recent industrial strikes concerning the salaries and wages of employees in the industry. This move has become an exception to section 198. However, will this ban by the motor industry be the beginning of more sectors calling for the ban of temporary employment services in pursuit to being part of the exception? This article will look at the problems faced by temporary employment services in South Africa, the consequences of the lack of enforcement of the laws governing this industry, as well as what South Africa can learn from the international and foreign community.

\section{South Africa}

The main statutory provision that regulates temporary employment services in South Africa is section 198 of the Labour Relations Act. Section 198(1) provides that:

198. Temporary Employment Services

(1) In this section, 'temporary employment services' means any person who, for reward, procures for or provides to a client other persons:

(a) who render services to, or perform work for, the client; and

(b) who are remunerated by the temporary employment service.

This indicates a very peculiar position for every party involved in this relationship. The employer, known as the labour broker, is responsible for all administrative duties concerning the client. The most obvious one being finding workers and those duties concerning their employees, be it the drafting of employment contracts, or the payment of their salaries/wages. The client has the duty to regulate the working environment for the employee in the workplace. The employee is the unlucky one in this whole tripartite relationship because he needs to comply with the instructions of both the client and his employer. Section 198 suggests that there is actually no relationship between the client and the employee even though the

5 Eg. COSATU, NEHAWU, NUMSA, SACCAWU, MEWUSA: (Report of the Portfolio Committee on Labour on the public hearings on Labour Broking, 23 March 2010, at 604 and 607).

6 Eg. APSO, North-West Province SA Organisation, Staffataclick (Report of the Portfolio Committee on Labour on the public hearings on Labour-Broking, 23 March 2010, at 597, 598, 638).

7 Banned officially on 16 September 2010 
client is the one who pays the salary of the employee (indirectly through the labour broker) and the employee works at the premises of the client.

\section{Section 198(4) states that:}

(4) The temporary employment service and the client are jointly and severally liable if the temporary employment service, in respect of any of its employees, contravenes:

(a) a collective agreement concluded in a bargaining council that regulates terms and conditions of employment;

(b) $\quad \ldots$

(c) the Basic Conditions of Employment Act;

(d) $\quad \ldots$

Section 198(4) indicates what both the client and the employer are jointly and severally liable for, this excludes unfair labour practices. I find this particular section problematic because case law ${ }^{8}$ has proved that one of the most unfair labour practices that temporary employees have to deal with is unfair dismissals (which are part of unfair labour practices) at the hands of the client. These unfair dismissals are justified by the employer by using the poor excuse that the employment contracts of the employees have come to an end by operation of law. This in most instances leads to the employee being left unemployed mainly because the dismissal was conducted by the client and there is no legal remedy for the employee because there is no legal relationship between the client and the employee. The employment contract that is concluded between the client and the labour broker in most instances protects both these parties by providing that the employment of the employee will be terminated at the instance of the client. ${ }^{9}$

Temporary employees are one of the most vulnerable groups of employees in South Africa because the usual profile of the average employee is, unskilled, poor, desperate for employment and unknowledgeable as to the tripartite relationship or their statutory and constitutional rights regarding employment. Most of these employees are paid below average wages/salaries, work overtime without any pay ${ }^{10}$ and are not allowed any leave. ${ }^{11}$ These employees do not know that they have a right of recourse against both the client and their employer. This predicament calls for the strengthening of

See NAPE $v$ INTCS Corporate Solutions (Pty) Ltd 20108 BLLR 852 LC where a dismissal that was deemed to be substantively unfair by the court; LAD Brokers (Pty) Ltd v Mandla 200122 ILJ 1813 (LC).

9 n 8 above, 4.

10 Report of the Portfolio Committee on Labour on the public hearings on LabourBroking, 23 March 2010, at 597, 598, 638.

11 Report of the Portfolio Committee on Labour on the public hearings on LabourBroking, 23 March 2010, at 597, 598, 638. 
section 198(4)(c) that makes the client and the employer jointly and severally liable for any contravened provision in the Basic Conditions of Employment Act. ${ }^{12}$ This Act states its purpose to be the advancement of 'economic development and social justice by [interalia] ${ }^{13}$ establishing and enforcing basic conditions of employment'. ${ }^{14}$

Section 198(4)(a) also makes the employer and client jointly and severally liable for any collective bargaining arrangement that has being contravened. In order for the employee to benefit from employee settlements achieved through collective bargaining, their employers must be a part of a registered bargaining council. Even if a temporary employment agency was part of a bargaining council, abiding to the terms of a bargaining council would prove to be a mission because the person who has to ultimately comply with the settlements is the client, and with the client not being the employer of the temporary employee and not registered as a party to a bargaining council, cannot be obligated to adhere to collective bargaining agreements. This is not in line with the right found in section 23(2) of the Constitution which is intended to allow every employee the right to benefit from bargaining council agreements, which is one of the advantages attached to being a member of a trade union.

Another problem that temporary employees face in South Africa is that they are seldom given the same treatment as permanent employees. They are usually the first people to be retrenched during bad economic times and in most instances receive lower wages than their permanent counterparts even though they perform the same job in the work place. The Employment Equity Act ${ }^{15}$ forbids any form of discrimination by the employer and the client to the employee and it also holds the employer and the client jointly and severally liable for any act of discrimination made against the employee. ${ }^{16}$ Section 1 of The Promotion of Equality and Prevention of Unfair Discrimination $\mathrm{Act}^{17}$ defines discrimination as being: ${ }^{18}$

... any act or omission, including a policy, law, rule, practice, condition or situation which directly or indirectly:

(a) imposes burdens, obligations or disadvantage on; or

(b) withholds benefits, opportunities or advantages from,

any person on one or more of the prohibited grounds.

Act 75 of 1997.

My addition.

Sec 2.

Act 55 of 1998.

Sec 57.

Act 4 of 2000 .

Sec 1. 
The Act also defines 'equality' as being inclusive of: ${ }^{19}$

... the full and equal enjoyment of rights and freedoms as contemplated in the Constitution and includes de jure and de facto equality and also equality in terms of outcomes.

Informing temporary workers about available permanent employment opportunities encourages 'employment security' as envisaged by the Constitutional Court in the case of Sidumo and another $v$ Rustenburg Platinum Mine and Others. ${ }^{20}$ The equal treatment of employees (regardless of them being temporary) will also allow them access to collective agreements of a bargaining council and also force employers to not replace permanent employees with temporary workers during industrial strikes and lock-outs. The practice of replacing workers with temporary staff during industrial action is not illegal in Germany; ${ }^{21}$ this is because temporary staff are given the choice of choosing whether or not they want to work for a client who is affected by industrial action. South Africa can learn from this by affording temporary employees with the same kind of arrangement followed by Germany or it can prohibit the employment of temporary employees during strikes and lock-outs. Treating workers equally in the workplace can also minimise the chances of temporary workers being the first amongst all the employees in the workplace to be retrenched. This would mean that workers will be retrenched based on, inter-alia, work performances and not on the fact that they are temporary employees.

\section{Namibian judgement}

Temporary Employment Agencies were banned in its entirety in Namibia following the promulgation of the 2007 Labour Act, in which section $128^{22}$ stipulated that the labour hiring industry was illegal based on the interest of decency and morality. The section 128 provision was challenged in the case of African Personnel Services (Pty) Ltd $v$ Government of the Republic and others. ${ }^{23}$ In this case the applicant (a labour broker) challenged the constitutionality of section 128 citing that the section was not in line with what the Namibian Constitution strived to achieve. The applicant lost the case in the

$\operatorname{Sec} 1$.

200712 BLLR 1097 (CC).

http://www.eurofound.europa.eu/eiro/studies/tn0807019s/de0807019q.htm

(accessed 20-21 October 2009); See also 'Guide to Private Employment Agencies, Regulation, Monitoring and Employment' (pdf file) and 'Private Employment Agencies, temporary agency workers and their contribution to the labour market' (pdf file) (accessed 21 October 2009).

22 Sec 128(4) Insofar as this sec interferes with the fundamental freedoms in Art $21(1)(j)$ of the Namibian Constitution, it is enacted upon the authority of sub art (2) of that Art in that it is required in the interest of decency and morality. 
court $a$ quo and amongst the reasons given by the court were the following: 24

(1) That the contract of employment had only two parties: the employer and the employee;

(2) That labour hire had no legal basis in Namibian common law, which is based on Roman Law;

(3) That the imposition of a third person, i.e. the labour hire company, in the employer-employee (relationship) was unlawful and;

(4) That the right protected by Article 21(1)j of the Republic of Namibia did not include labour hire companies.

It is important to note that the Namibian High Court did not take cognisance of Convention 181 of the International Labour Organization (ILO), which is the Private Employment Agencies Convention. 25 This Convention clearly shows the ILO's stance in supporting the strict regulation of private employment agencies and not the ban thereof.

The loss of the applicant in the High Court resulted in the applicant challenging the court a quo's decision in the Supreme Court of Namibia. The appellant succeeded in his appeal in that the Supreme Court struck down the High Court's decision. The Supreme Court found section 128 to be an unreasonable infringement of the constitutional right to practice any profession, or carry on any occupation, trade or business. The Supreme Court found that the system that was used as a form of contract labour hire by the South West Africa Native Labour Association (SWANLA) was used with the objective of advancing the discriminatory laws of apartheid; those laws the court stated do not apply in Namibia anymore. The court held that there was "no rational relationship between the immoral SWANLA-like contract labour system and the prohibition of agency work on grounds of decency and morality'.26 Unlike the current system in Namibia, with the SWANLA labour hire system, the worker providing the services was known as the employee and the user enterprise as the eventual employer. In addition, the court stated that the labour hiring industry needed strict regulation in order to protect the rights of workers because they were the most exploited in the industry. The court, inter alia, took cognisance of the ILO favouring employment agencies through convention 181 and also indicated that it would be permissible to prohibit employment agencies and clients from employing employees who are contracted temporarily to work permanently for the client. 09-7/NLJ_section_7.pdf (accessed 5 July 2010).

25 Convention 181, 1997 (Namibia is not a member of this convention).

26 Pgs 81 and 82 of official judgment. 
The applicant challenged the constitutionality of section 128 on the protected fundamental right to practice any profession, or carry on any occupation, trade or business. South Africa also has the same constitutionally protected fundamental right; however this right is only available to the citizens of South Africa. According to the South African Citizenship Act, ${ }^{27}$ the status of a citizen is only given to natural persons; this is because the Act only makes provision for the acquisition of citizenship in the Republic through birth, ${ }^{28}$ descent ${ }^{29}$ and naturalisation. ${ }^{30}$ Temporary employment services will be regarded as juristic persons because they are registered businesses. In order for temporary employment services to protect their industry in court, instead of relying on section 22 of the Constitution like the African Personnel Services, they will rely on section 18 of the Constitution, which provides for the right to freedom of association. Their argument will be strengthened further by the fact that South Africa ratified the Freedom of Association and Protection of the Right to Organise Convention on 19 February 1996. The Constitution stipulates that the right to freedom of association is afforded to everyone, and the courts might interpret 'everyone' as being both natural and juristic persons. The right to freedom of association allows people to establish and/or join organisations of their own choice at anytime.

\section{$4 \quad$ International perspectives}

\subsection{C181: Private Employment Agencies Convention ${ }^{31}$}

This Convention further strengthens the points that I have highlighted above. The main factors being that temporary employees must never be denied the right to freedom of association ${ }^{32}$ and the existence of the right to bargain collectively from arrangements ${ }^{33}$ concluded by bargaining councils in order to promote a uniform approach in handling labour matters in a country. The Convention also emphasises that a member state must take the necessary precautions and measures in its country in order to ensure that temporary employees are adequately protected by the malpractices of temporary employment services. They briefly specify that this can be in relation to minimum wages, ${ }^{34}$ access to training ${ }^{35}$ and occupational health and

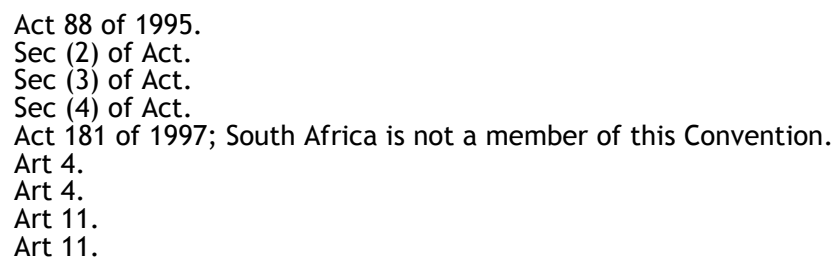


safety in the workplace. ${ }^{36}$ Although South Africa has not ratified this Convention, it can learn what the international standards require from a country that has legalised the operation of labour brokers. It is undeniable that the international community expects temporary employees to be treated in the same way as permanent employees and that there can never be an exception to this rule.

\subsection{Foreign Law}

In the State of Victoria, under the Outworkers (Improved Protection) Act 2003, a worker is empowered to bring legal proceedings against any person that they believe to be their employer. Should that person not in fact be their employer, the respondent to the claim may in turn pass the demand to another party. Adapting this model to the situation of private employment agencies would thus lead to a worker being able to bring proceedings against their presumed employer (the user enterprise), with the user enterprise therefore being liable if it were unable to succeed in showing that the private employment agency ${ }^{37}$ was responsible, or in proceedings intended to enforce such an obligation. 38

The European Directive on Temporary Agency Work (TAW Directive) was adopted in 2008 and it must be implemented by all the members of the European Union. The main objective of the TAW Directive is the equal treatment of all employees in the workplace regardless of whether they are temporary or permanent workers. In addition to the principle of equality, the Directive also states that a temporary employee is to be informed about permanent opportunities in the workplace in order to encourage permanent employment.

\subsection{Proposals}

A substantial number of labour inspectors must be appointed to deal solely with problems related to temporary employment services. They must monitor whether or not temporary employment agencies comply with various laws such as compliance with the Basic Conditions of Employment Act, ${ }^{39}$ whether or not employers are informing workers of their rights in the workplace in order to promote transparency etc. The employment of labour inspectors who will deal solely with issues arising from temporary employment agencies will provide for better implementation of labour laws.

Art 11.

The term used internationally for temporary employment service.

(accessed 17 May 2010) 'RE: Labour law Namibia, Industrial Relations (ILO Pretoria)' E-mail to Erenstein ya Taivo in Windhoek (accessed May 2010). 
Temporary employees must never be used to replace workers who are on strike. Alternatively, these workers must be given the choice to choose whether or not they want to work in an environment that is affected by an industrial action.

Responsible temporary employment agencies and labour inspectors must form a pact with the SAPS that will see the eradication of temporary employment agencies that are operating without any certificate.

Temporary employment agencies must inform their employees about permanent employment opportunities so that temporary employees can be exposed to the same permanent employment opportunities as their counterparts.

The client must also be legally responsible for ascertaining that all employees providing their services and labour to the enterprise have been contracted with their agencies and that the temporary employment agencies they are using are operating legally.

There are two categories of labour inspectors in South Africa, firstly labour inspectors that deal solely with occupational health and safety measures and secondly labour inspectors that deal with labour relations excluding labour practices. The Commission for Conciliation Mediation and Arbitration (CCMA) is the body that has the task to deal with matters concerning unfair labour practices. Most of the employees whose employers are labour brokers complain of unfair labour practices such as refusal of leave from their employers, not getting paid for working overtime, insufficient (or in extreme cases no) payment of wages etc. I would recommend that a department be established within the CCMA that can deal specifically with complaints arising from employees in the temporary employment industry. Employees who have any issues arising from work can go to this department and lay a complaint that will be administered efficiently by people who are knowledgeable about this sector. These employees must be informed of their right to do this if need be.

\section{Conclusion}

The issue of temporary employment agencies in South Africa is a very complex area that requires immediate intervention. Generally employees of these agencies are exploited without any assistance from the government. These employees are the most vulnerable group and their fundamental rights of fair labour practices and just administrative action must be protected. In order to enforce compliance, I believe that there must be stringent implementation methods that will allow for the constant monitoring of these agencies. Imperative intervention is required, but the government must do this with the consultation of various parties such as some of the employees 
themselves, responsible temporary employment agencies and labour organisations such as the National Economic Development and Labour Council (NEDLAC) and the South African Society for Labour Law (SASLAW) so that these regulations are formulated with an understanding of every individual that is affected. I am in favour of not only strict regulations for temporary employment agencies but also for strict regulations of labour inspectors. Labour inspectors need to be monitored so that they do their jobs accurately, effectively and efficiently. South Africa needs to take extensive care in providing decent work to every employee in every workplace as required by the ILO, of which South Africa is a member of. 